\title{
An Investigation of the Effectiveness of the Division of Corporate Finance as a Monitor of Financial Reporting
}

\author{
Jennifer Echols Edmonds
}

\begin{abstract}
Dissertation submitted to the faculty of the Virginia Polytechnic Institute and State University in partial fulfillment of the requirements for the degree of

Doctor of Philosophy

In

General Business, Accounting

C. Bryan Cloyd (Chair)

Robert M. Brown

T. Bowe Hansen

John J. Maher

Sattar Mansi

December 14, 2011

Blacksburg, VA
\end{abstract}

Keywords: Forward Earnings Response Coefficient, Disclosure Quality, Comment Letters Copyright 2011, Jennifer E. Edmonds 


\title{
An Investigation of the Effectiveness of the Division of Corporate Finance as a Monitor of Financial Reporting
}

\author{
Jennifer Echols Edmonds
}

\begin{abstract}
:
This study uses the Securities and Exchange Commission's (SEC) comment letters to investigate the SEC's role as a monitor of financial reporting. I examine whether the SEC effectively comments on firms with poor disclosure quality. I utilize forward earnings response coefficients (FERC) as a measure of the market's perception of disclosure quality. I expect comment letter firms to have lower disclosure quality and thus lower FERCs. Secondly, within the firms selected for comment, I investigate whether the Division allocates a greater amount of resources towards firms with more severe disclosure deficiencies. Results indicate that comment letter recipients have significantly lower forward earnings response coefficients than nonrecipients. Results also document that comment letter recipients have lower contemporaneous earnings response coefficients than non-recipients. These findings are consistent with the DCF being effective in selecting firms that are perceived by the market as having low disclosure and earnings quality. However, within comment letter firms, I am unable to provide any evidence that the DCF allocates more resources to firms with lower forward earnings response coefficients.
\end{abstract}




\section{DEDICATION}

I dedicate this dissertation to the innocent victims of the April $16^{\text {th }}$ tragedy. My heart and prayers go out to all of their families and friends. God Bless the Virginia Tech community. We will never forget. 


\section{ACKNOWLEGEMENTS}

First and foremost, I would like to thank my dissertation chair, Bryan Cloyd for providing guidance, encouragement, and support throughout the process. I would also like to thank Robert M. Brown, Bowe Hansen, Jack Maher, and Sattar Mansi for serving on my committee and providing me with invaluable feedback as I completed this process.

Thank you to the Accounting and Information Systems department for the financial support that was provided both for my academic program through multiple scholarships. A special thank you goes to Phyllis Neece, Katherine Caldwell, and Arnita Perfater for all of their help during my time at Virginia Tech.

I would like to thank my friends, James Long, Lasse Mertins, Mollie Adams, Megan McInerney, Lucian Zelazny, Jim Penner, Michele Meckfessel, Becky Fay, Ryan Leece, Kerry Inger, Todd White, Michael Olzanski, Eric Negangard, Jonathan Pyzoha, and Owen Brown. All of you contributed to this success of this process in one way or another. It was a pleasure getting to know you.

Finally, I would like to thank my family. I would not have made it through this process without the guidance and support of Leslie Echols, Wayne Echols, Jackson Echols, Tom Edmonds, Cindy Edmonds, Sammy Edmonds, Fonda Carter, Jack Echols, Sue Echols. Finally, I would like to thank my husband, Chris, for his love, support, and patience. 


\section{TABLE OF CONTENTS}

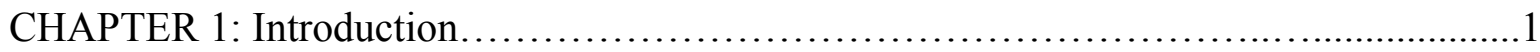

CHAPTER 2: Comment Letter Background........................................4

CHAPTER 3: Literature Review..................................................

CHAPTER 4: Hypothesis Development....................................... 9

CHAPTER 5: Research Design...................................................... 12

5.1 Measuring the FERC and ERC of Comment Letter Recipients and Non-

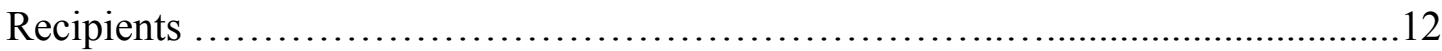

5.2 DCF Resource Allocation... ............................................... 16

CHAPTER 6: Data and Descriptive Statistics............................................... 19

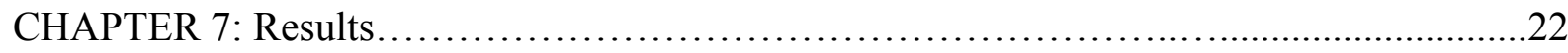

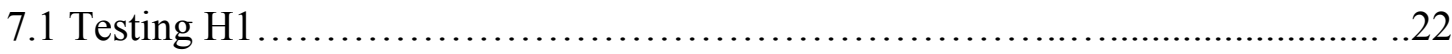

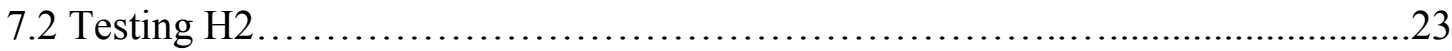

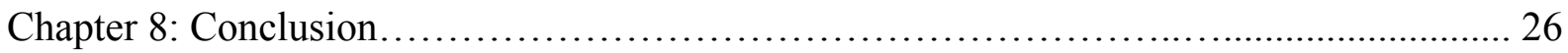

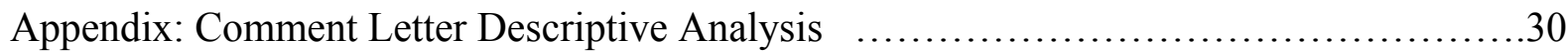




\section{LIST OF FIGURES}

FIGURE 1: Division of Corporate Finance (DCF) Offices by Industry............41

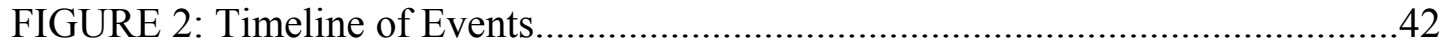

FIGURE 3: Area of Comment Letter by Issue Category for 2005 to 2009 ..........43

FIGURE 4: Area of Comment Letter Focus by Filing Type for 2005 to 2009 ........44 


\section{LIST OF TABLES}

TABLE 1: Sample Selection Process Comment Letter Conversations..........................45

TABLE 2: Descriptive Statistics CL Firms and Non-CL Firms...........................46

TABLE 3: Pearson Correlation Coefficients.......................................47

TABLE 4: FERC Model.........................................................48

TABLE 5: FERC Model with Additional Controls........................................49

TABLE 6: FERC Severity of Comment Letter Case.....................................50

TABLE 7: Category Definitions................................................ 51

TABLE 8: Comment Letters across DCF Offices for the 2005 -2009 Period.................52

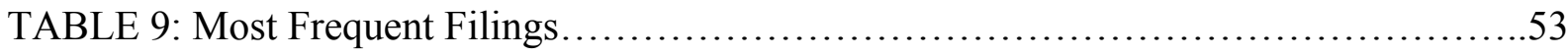

TABLE 10: Top Comment Letter Issues by Categories ................................54

TABLE 11: Top Comment Letter Issues for the 2005-2009 Period .......................55

TABLE 12: Top Comment Letter Issues by DCF Office............................56

TABLE 13: Issue Analysis Comparing Small and Large Filers...............................58

TABLE 14: Descriptive Statistics for All Comment Letter Cases........................61

TABLE 15: Descriptive Statistics for 10K and 10Q Comment Letter Cases..................62

TABLE 16: Spearman Correlation Coefficients for Top Issues across DCF Offices...........63 


\section{INTRODUCTION}

This study uses Securities and Exchange Commission (SEC) comment letters to investigate the SEC's role as a monitor of financial reporting. The SEC's Division of Corporate Finance (DCF) reviews filings made under the Securities Act of 1933 and 1934 to identify deficiencies and enhance material disclosures. While research is prevalent concerning SEC enforcement actions, relatively little is known about the Commission's method of reviewing and selectively commenting on filings. The SEC's recent endeavor to make comment letters publicly available on EDGAR provides a novel context for investigating how effectively the SEC identifies deficiencies and allocates resources towards comment letter recipients.

An effective monitoring process is relevant to the Division's success given the importance of maintaining a reliable U.S. financial reporting regime. The Sarbanes-Oxley Act of 2002 (SOX) requires the Division to review all 13,000 public companies at least once every three years. The Division is also responsible for performing full reviews on initial public offerings, contested proxy solicitations, tender offers and going private transactions due to the potential impact on investors. The DCF conducts this extensive monitoring role with an extremely limited budget. According to a recent audit report, the DCF spends approximately $\$ 125$ million reviewing and commenting on public company filings (SEC 2006 Audit Report \#401) ${ }^{1}$. The scope of the DCF's reviews coupled with a limited budget pose a threat to the DCF's ability to make meaningful improvements unless the DCF focuses its attention and resources on firms with the greatest deficiencies.

This study contributes to an emerging body of literature examining the comment letter process. Instead of focusing on the market effects related to receiving a comment letter (Chen

\footnotetext{
${ }^{1}$ The SEC Audit report \#401 for 2006 indicates that the DCF has 515 staff and $80 \%$ are assigned to review filings.
} 
and Johnston 2010; Ertimur and Nondorf 2008), my analysis is centered on the effectiveness of the DCF in selecting firms and allocating resources. Specifically the study investigates whether the DCF selects and allocates resources towards firms that investors perceive as poor disclosers. Since the DCF was organized with the specific purpose of increasing the disclosure quality and transparency of financial reports available to investors, it is important to understand whether the DCF is focusing its resources on firms that investors identify as having disclosure issues.

To investigate the effectiveness of the comment letter process, I examine whether the DCF comments on firms that the market perceives as having poor disclosure quality. I utilize the forward earnings response coefficient (FERC) as a measure of the market's perception of disclosure quality. Collins, Kothari, Shanken and Sloan (1994) introduced the FERC as a measure of the association between current stock returns and future earnings. While prior research documents a positive relation between the level of voluntary corporate disclosure and the informativeness of current stock prices about future earnings (higher FERC)(Gelb and Zarowin 2002; Lundholm and Myers 2002), this is the first study to my knowledge to utilize the FERC as a measure of disclosure quality in comment letter firms. Analysts, investors and regulators rely on disclosure for information about the amount, timing and uncertainty of future earnings. Theoretically, more or better disclosures should help investors improve their forecast of future earnings, strengthening the relation between a firm's current stock returns and future earnings. Therefore, I expect comment letter firms to have lower disclosure quality and thus lower FERCs. Secondly, within the firms selected for comment, I investigate whether the DCF allocates a greater amount of resources towards firms with more severe disclosure problems (i.e. lower FERCs). I utilize three distinct measures to proxy for the amount of resources the DCF allocates to a comment letter case including the number of issues identified in the comment 
letter(s), the number of rounds in the comment letter conversation, and the time span from the receipt of the initial comment letter until the comment letter is resolved.

Results indicate that comment letter recipients have significantly lower forward earnings response coefficients (FERC) than non-comment letter recipients. This finding is consistent with the conjecture that the DCF is effective in selecting firms that are perceived by the market as having low disclosure quality. Secondly, results indicate that comment letter recipients also have significantly lower earnings response coefficients (ERC). This result indicates that comment letter firms have poor earnings quality as well as poor disclosure quality. However, within comment letter firms, I am unable to provide any evidence that the DCF allocates more resources to firms with lower forward earnings response coefficients. These findings are germane to our understanding of the SEC accomplishing its goal as a monitor.

The remainder of this paper is organized as follows. Section two provides background information on the comment letter process. Section three discusses related literature. Section four motivates the hypotheses. Section five describes the sample and research design. Descriptive statistics are presented in section six and results are presented in section seven. Finally, section eight includes concluding remarks and suggestions for future research. Section nine includes an appendix with further descriptive analyses of comment letter firms. 


\section{COMMENT LETTER BACKGROUND}

The Division of Corporate Finance is responsible for monitoring corporate disclosures to the investing public. It conducts multiple review types of public companies which primarily include full (accounting and legal); financial statement (accounting); legal; targeted (specific issue); and preliminary (initial review typically of 10-K). The type of filing dictates whether the DCF conducts a full or partial review. The DCF automatically performs a full review on any filing dealing with a firm's initial entry into the federal disclosure system (IPO), contested proxy solicitation, tender offer, or going private filing because these filings could have a material effect on investors. Other filings are not reviewed upon every submission but are periodically reviewed by the DCF.

According to the Sarbanes-Oxley Act of 2002, the DCF must review all public companies at least once every three years; however, some companies may be reviewed every year (SOX 2002). The Division utilizes the criteria laid out in the Sarbanes-Oxley Act in conjunction with its private criteria to select risky firms to review. The Division performs preliminary reviews of firms' $10 \mathrm{~K} / 10 \mathrm{Q}$ in order to identify deficiencies and determine whether further review is necessary. This initial evaluation helps the DCF decide how to allocate resources among firms with differing levels of disclosure issues. The reviews are conducted by one of twelve DCF offices $^{2}$ according to the firm's industry (See Figure 1). ${ }^{3}$ In order to gain insight into the DCF's private selection process, I focus on firms that were not only reviewed but were also selected to

\footnotetext{
${ }^{2}$ Each DCF office employs approximately 25 to 35 staff (www.sec.gov).

${ }^{3}$ Health care and insurance, Consumer products, Computers and online services, Natural resources and food, Structured finance, transportation, and leisure, Manufacturing and construction, Financial services, Real estate and business services, Beverages, apparel and health services, Electronics and machinery, and Telecommunications.
} 
receive a comment letter concerning one or more issues. ${ }^{4}$ Specifically, I investigate firm's receiving comment letters related to deficiencies in their 10K or 10Q. In the period 2005-2009, the DCF commented on the 10-K more than any other filing making it particularly relevant for investigation.

[Figure 1]

The SEC does not release information regarding firms subject to review but not selected to receive a comment letter. ${ }^{5}$ A public record is only provided if the DCF identifies an issue during the review. At this time, the DCF sends a comment letter to the firm. When a firm receives a comment letter, it has ten business days to reply to the SEC. It is normal to have several rounds of comments from the staff and responses from the filer before the issues are resolved. I refer to the total correspondence (all comment letters and response letters) between the staff and filer concerning a set of issues as a comment letter case. For example, the DCF initially sends a comment letter about $X$ issues and the firm sends a response letter explaining either how it corrected the issues or why the issue is not a problem. This type of communication continues until the DCF closes the case. Since the DCF reviews firms annually, it is also possible for a firm to have more than one comment letter case if the firm has been a comment letter recipient in more than one year in the sample period. For instance, the SEC could select a firm to receive a comment letter in 2005 and send the same firm a comment letter in 2007 which would constitute two comment letter cases.

\footnotetext{
${ }^{4}$ The SEC does not send comment letters to every firm that it reviews. My sample is made up of firms reviewed by the SEC and chosen by the SEC to receive a comment letter. The SEC's decision to send a comment letter should indicate that an issue was discovered which must be resolved.

${ }^{5}$ It is impossible to compare firms identified for review but NOT commented on by the DCF to the firms reviewed and selected to receive a comment letter, because a record only exists if there is a comment letter sent to the firm.
} 
Taken as a whole, the comment letter process represents a dialogue between the DCF and firm management with the DCF taking the perspective of an investor. The DCF comments on a wide range of filings and uncovers a variety of issues. From 2005-2009, the Division commented on 99 different types of filings which included comments on 1,160 unique issues as coded by Audit Analytics. The primary focus of the DCF has been general accounting and disclosure related to U.S. GAAP with issues such as revenue recognition, debt, warrants and equity, and executive compensation frequenting the list of popular topics. Depending on the magnitude of the discovered issues, the DCF may request supplemental materials, require the filer to change future filings or require the filer to restate the current or past filings. The DCF and firm engage in an average of 6 rounds of communication prior to resolving the issues which, on average, takes approximately 66 days. ${ }^{6}$

\footnotetext{
${ }^{6}$ From data reported on Audit Analytics.
} 


\section{LITERATURE REVIEW}

Most research on the SEC's capacity as a monitor investigates the impact of receiving a comment letter. Chen and Johnston (2010) examine the market behavior around earnings announcements for a sample of firms receiving a comment letter related to their $10 \mathrm{~K} / 10 \mathrm{Q}$. The authors hypothesize and find a reduction in return volatility and trading volume at ensuing earnings announcements. The authors surmise that SEC scrutiny in the form of a comment letter encourages firms to enhance their financial disclosures. Higher quality disclosures facilitate the flow of useful information which decreases information asymmetry and increases precision in investors' pre-announcement beliefs. The authors further document a spillover effect where industry peers, not subject to a SEC comment letter, experience similar market effects. As hypothesized, peers are more likely to mimic the disclosure behavior of comment letter recipients when SEC scrutiny is intense in their respective industry. In a similar study, Ertimur and Nondorf (2008) explore whether receiving a comment letter affects the information environment of firms undergoing an initial public offering (IPO). Results do not support the improved information environment hypothesis; however, the study provides evidence that IPO firms with higher managerial expertise receive less severe comment letters. The samples of each study are quite different and could contribute to the mixed results. It is possible that firms undergoing an IPO may be under increased scrutiny and have higher quality disclosures in the pre-comment letter period than other firms. Pre-comment letter financial reporting quality may be an important determinant to a successful comment letter process. Instead of investigating the post-comment letter period, I examine the disclosure quality of firms prior to receiving a comment letter. My analysis will shed light on whether the SEC is selectively commenting on and allocating resources towards firms with poor disclosure quality. 
Another stream of research investigates the financial reporting process of the DCF. These studies are primarily interested in the DCF's activities. Gao et al. investigate the DCF's monitoring role as it relates to prompting restatements (2010). Results document that the DCF is less likely to require firms to restate than other monitors (i.e. external auditors, management) making the DCF "monitor of last resort". The study also shows that differences exist in the number of restatements initiated across the DCF offices. Research concerning the DCF also provides mixed evidence concerning whether the characteristics of comment letter recipients are consistent with the Sarbanes-Oxley Act selection criteria (Chen and Johnston 2010, Ertimur and Nondorf 2008). Therefore, it is unclear which firm characteristics the DCF emphasizes when selecting $10 \mathrm{~K} / 10 \mathrm{Q}$ filings for comment. 


\section{HYPOTHESES DEVELOPMENT}

It is an empirical question whether the SEC allocates resources towards firms with the greatest disclosure deficiencies. The question is really two pronged. First, is the DCF commenting on firms with poor disclosure quality? And second, within the firms selected by the DCF for comment, are a greater amount of resources being allocated to firms with more severe disclosure problems? The first question investigates the effectiveness of the DCF's selection and review process in terms of commenting on firms perceived by investors to have low disclosure quality. While related, the second question focuses on the effectiveness of resource allocation once the DCF initiates a comment letter case.

The two processes are distinctly different in that the Sarbanes-Oxley Act provides guidance on how the DCF should select firms for review (i.e. selection process) but provides no guidance as to how the DCF should allocate resources among selected firms. The legislation in the Sarbanes-Oxley Act requires the DCF to review public companies at least once every three years; however, the DCF must consider more than timing. To increase the effectiveness of the monitoring process, the Sarbanes-Oxley Act set forth a list of factors to help the Division select firms that are more likely to exhibit financial reporting deficiencies. The legislation provides no guidance on how the criteria should be measured leaving implementation up to the DCF staff. While vague, the legislation emphasizes firms with poor financial reporting quality (recent restatements, stock price volatility, and emerging firms with disparities in P.E. ratios) and the remaining criteria point to large firms either defined by market capitalization or by the extent to which the firms' operations impact a material sector of the economy. The DCF acknowledges that it also has private criteria for selecting companies. Yet, in order to preserve the integrity of the process, the DCF will not unveil specifics. The DCF utilizes the public and private criteria as 
part of its risk-based approach to select firms for review that are more likely to exhibit deficiencies. The process is not random and certain companies are more likely to be reviewed and thus receive a comment letter.

The DCF works on behalf of investors to monitor public company filings for transparency and completeness. To select firms for comment, staff members read individual filings to identify disclosures that seem inadequate, incorrect, or unclear to potential investors. ${ }^{7}$ When an issue is identified, a comment letter is sent to the firm outlining staff concerns and potential deficiencies including how the DCF believes the disclosure could be improved. Given the DCF's mission, one would expect the firms targeted by the DCF to have poor disclosure quality. Additionally, the requirements in the Sarbanes-Oxley Act should guide the DCF towards firms with poor disclosure. Therefore, I pose the following hypothesis related to the characteristics of comment letter recipients:

H1: Comment letter recipients' financial disclosures are perceived by investors to be less informative than non-comment letter recipients' financial disclosures.

The advantage of testing $\mathrm{H} 1$ is that it provides evidence as to whether the DCF is effective in targeting firms that investors perceive as having a poor disclosure environment. However, it is not possible to discern whether supporting evidence is the result of the DCF targeting firms based on the Sarbanes-Oxley Act criteria or the DCF's internal review process. To isolate the effectiveness of the DCF's internal review process, I also investigate how effectively resources are allocated within DCF comment letter cases. As previously mentioned, a comment letter case encompasses all of the correspondence between the DCF and firm

\footnotetext{
${ }^{7}$ Two staff members are assigned to each filing. Each staff member independently reads the filing to identify deficiencies and then the two staff members compare the results of their independent reviews.
} 
(comment and response letters) resulting from an annual review. Therefore a comment letter case could include multiple letters and issues identified by the DCF. Additionally, the number of rounds and length of comment letter cases can vary depending on the amount of time it takes to resolve the firm's deficiencies. Once a firm is selected to receive a comment letter, the DCF allocates resources based on the staff members' reading of the firm's filings. Given that the DCF has limited resources, I predict that once the DCF has decided to open a case, the amount of resources spent on the case will vary inversely with the disclosure quality of the firm. I pose an additional hypothesis related to the resources allocated within comment letter cases.

H2: Comment letter recipients with disclosures that investors perceive as less informative are allocated more resources by the DCF than recipients with disclosures that are perceived by investors to be more informative.

Hypothesis 2 also relates to the disclosure quality of comment letter firms; however, it addresses the resource allocation decisions of the DCF more directly. Hypothesis 1 relates to the type of firms reviewed and selected to receive a comment letter which is a function of two mechanisms. Specifically 1) the criteria required by the Sarbanes-Oxley Act could lead the DCF to identify a firm as high risk, or 2) the firm's financial reporting quality could trigger the DCF's interest. The principal interest of Hypothesis 2 is the DCF's resource allocation decisions after the firm has been identified. The amount of resources the DCF allocates to the comment letter firm is a function of the DCF staff's reading of the filing(s) in question, independent of the Sarbanes-Oxley Act selection criteria. This allows me to get at the effectiveness of the process designed by the DCF irrespective of the guidance within the Sarbanes-Oxley Act. Analysis of these hypotheses should provide beneficial insight into the DCF's identification process and resource allocation decisions. 


\section{RESEARCH DESIGN}

\subsection{Measuring the FERC and ERC of Comment Letter Recipients and Non-Recipients}

Prior disclosure research utilizes financial analysts' evaluations of corporate disclosure practices, published in the Corporate Information Committee of the Financial Analysts

Federation. The committee was formed by the Association for Investment Management and Research (AIMR) and relied on buy and sell side analysts with industry specific expertise. The FAF scores provided an overall measure based on analysts' perceptions of disclosure quality in three areas 1) annual report, 2) quarterly reports, and 3) other information such as managements' communication with analysts. ${ }^{8}$ Several important contributions stemmed from the FAF scores including evidence that high discloser firms have more accurate analyst forecast (Lang and Lundholm 1996), lower cost of debt (Sengupta 1998), and lower bid-ask spreads (Welker 1995; Healy, Hutton, and Palepu 1999). However, the FAF scores are only available for years prior to 1996 making it necessary to utilize a different measure for disclosure quality in recent years.

An examination of prior literature yields multiple papers dealing with the relation between disclosure, stock returns, and future earnings. While past research documents a relation between disclosure quality (measured by FAF scores) and analyst forecast measures (analyst forecast accuracy, analyst dispersion), recent studies use a more direct approach. Instead of relying on analyst forecast accuracy as a proxy for the informativeness of stock returns, Lundholm and Myers (2002) and Gelb and Zarowin (2002) directly measure the relation between current returns and future earnings. A benefit of using a direct measure such as the FERC is that it limits other possible explanations for the results. For instance, Gelb and Zarowin (2002) point

\footnotetext{
${ }^{8} \mathrm{~A}$ firm is given a score in each of the three categories. The overall disclosure quality score is a weighted average of the three scores.
} 
out that the accuracy of analysts' forecasts could be a result of firms doing a better job managing their analyst relationship (i.e. whisper numbers) as opposed to direct evidence of more informative stock returns.

Lundholm and Myers (2002) and Gelb and Zarowin (2002) developed their regression model based on Collins, Kothari, Shanken and Sloan's regression of annual returns on contemporaneous earnings changes and future earnings changes(1994). Collins, Kothari, Shanken and Sloan (1994) supplemented future earnings changes to the regression of annual stock returns and contemporaneous earnings changes (ERC) to increase the explanatory power $\left(\mathrm{R}^{2}\right)$ of the model. On the other hand, Lundholm and Myers (2002) and Gelb and Zarowin (2002) were specifically interested in the impact of a firm's disclosure activity on the relationship between current stock returns and future earnings (FERC). Both studies hypothesize and find that increased disclosure results in a stronger relation between current stock returns and future earnings (higher FERC).

A firm's annual stock return is a byproduct of three items 1) the unexpected segment of the current year's earnings, 2) changes in expectations about future earnings and 3) random noise. When a firm uses its disclosure activity to provide relevant information about future earnings, the current returns will reflect the future earnings news. Lundholm and Myers (2002) assert that the new mix of information "brings the future forward" by altering investors' expectation of future earnings and resulting in a stronger relation between the current return and future earnings (higher FERCs). Therefore, Gelb and Zarowin (2002) and Lundholm and Myers (2002) are credited with contributing an empirical measure of the benefits associated with enhanced voluntary disclosure. 
I utilize Lundholm and Myers (2002) and Gelb and Zarowin's (2002) empirical measure (FERC) to further investigate disclosure quality in the absence of FAF scores ${ }^{9}$. My study differs from prior research in significant ways. First prior research utilizes the FERC as a test of the relative informativeness of high and low disclosers and examines whether disclosure is priced using analysts' ratings of disclosure as a proxy for the firm's disclosure quality. I extend the literature by using the FERC to investigate whether the DCF's review process is valuable. Specifically, I examine whether the DCF effectively targets firms with poor disclosure quality during the comment letter process. If the DCF successfully identifies firms with deficiencies in disclosure, comment letter firms should have lower FERCs than non-comment letter firms. Based on prior literature (Gelb and Zarowin 2002; Lundholm and Myers 2002), I estimate the following FERC equation.

$M A R_{t}=\alpha_{0}+\alpha_{1} \Delta E_{t-1}+\alpha_{2} \Delta E_{t}+\alpha_{3} \Delta E_{t+1}+\alpha_{4} M A R_{t+1}+\alpha_{5} C L_{t+1}+\alpha_{6} \Delta E_{t-1} * C L_{t+1}+\alpha_{7} \Delta E_{t} * C L_{t+1}+\alpha_{8} \Delta E_{t+1}$

* $C L_{t+1}+\alpha_{9} M A R_{t+1} * C L_{t+1}+\varepsilon_{t}$

Where:

$M A R t=$ the firm's market adjusted stock return measured over the 12 month period ending three months after fiscal year t;

$\Delta E t-1=$ the earnings change for fiscal years t- 1 scaled by the stock price at three months after the beginning of fiscal year $t$;

$\Delta E t=$ the earnings change for fiscal years $\mathrm{t}$ scaled by the stock price at three months after the beginning of fiscal year $\mathrm{t}$;

$\Delta E t+1=$ the earnings change for fiscal years $t+1$ scaled by the stock price at three months after the beginning of fiscal year $t$;

$C L_{t+1}=1$ if the firm received a comment letter in year $\mathrm{t}+1 ; 0$ otherwise

\footnotetext{
${ }^{9}$ Lundholm and Myers (2002) and Gelb and Zarowin (2002) use FAF disclosure ratings as an exogenous measure of firms' disclosure quality and document that high disclosure firms have stock returns that are more informative about future earnings.
} 
The $\mathrm{MAR}_{\mathrm{t}}\left(\mathrm{MAR}_{\mathrm{t}+1}\right)$ is the 12 month market adjusted return starting three months after the end of fiscal year $\mathrm{t}(\mathrm{t}+1) . \mathrm{CL}_{\mathrm{t}+1}$ is one if the firm received a comment letter during the $\mathrm{MAR}_{\mathrm{t}+1}$ return window. The return windows are expressed graphically in Figure 2.

[FIGURE 2]

Instead of capturing firm specific FERCs, the model looks at the cross-section and estimates an overall FERC for comment letter firms and compares it to an overall FERC for noncomment letter firms. The coefficient on $E_{t+l}$ is the forward earnings-response coefficient $(F E R C)$. It is expected to be positive. $E_{t-1}$ is also included as a separate variable so that a specific form of the time-series process of earnings is not imposed (Collins, Kothari, Shanken, and Sloan 1994) and I expect it to be negatively related to $\mathrm{R}_{\mathrm{t}}$. The coefficient on $E_{t}$ is the contemporaneous earnings response coefficient. $R_{t+1}$ is the future period returns. Future period return is included because using the actual change in future earnings causes an errors in variable problem. Collins, Kothari, Shanken, and Sloan (1994) point out that theoretically the unobservable expected change in earnings should be included in the model. If left uncorrected, the future ERC will be biased downward. To correct for the problem, it is necessary to include a variable that is correlated with the measurement error in the independent variable yet uncorrelated with the dependent variable. I follow Collins, Kothari, Shanken, and Sloan (1994) and include the future return in the regression.

I augment this model by including an indicator, $\mathrm{CL}_{\mathrm{t}+1}$, to compare the FERC of comment letter recipients to the FERC of non-recipients. I examine FERCs of the two groups in the period prior to receiving the comment letter because the difference between the two groups' disclosure quality (FERC) should be the greatest prior to the DCF review. See Figure 2 for a timeline of 
events. Recent research shows that the DCF's review has a significant impact on firms' information environment as a result of actions taken to improve disclosure quality in response to the comment letter (Chen and Johnston 2010). Therefore, the disclosure quality of comment letter recipients and non recipients may become more similar subsequent to receiving the comment letter. The primary coefficient of interest is $\alpha 8$ which represents the interaction between $E_{t+1}$ and $\mathrm{CL}_{\mathrm{t}+1}$. I expect comment letter recipients to have lower FERCs and expect $\alpha 8$ to be negative. A negative coefficient would support the premise that comment letter firms suffer from lower disclosure quality which makes it more difficult for investors to predict future earnings.

The coefficient on $\alpha 7$ represents the difference in contemporaneous ERCs between comment letter recipients and non-recipients. It is difficult to predict which group will have higher contemporaneous ERCs. Prior literature documents that high discloser firms typically also have more good news. Following this line of research, high disclosers (non-CL firms) should have higher contemporaneous ERCs than low disclosers (Basu 1997). However, Gelb and Zarowin (2002) point out that the information impounded in the current earnings of high discloser firms may have already been impounded in their stock prices during the prior period. Therefore, firms with high disclosure quality may have lower earnings quality than firms with lower disclosure quality. Since theory could support either direction, I have no expectation for the sign on the coefficient.

\subsection{DCF Resource Allocation}

The second part of my analysis investigates whether the DCF allocates more resources towards firms with poorer disclosure quality. I utilize several measures to proxy for the amount of resources the DCF allocates to a comment letter case. First I use the number of issues (Issues) 
identified in the comment letters. I speculate that if the DCF identifies more comment letter issues then there is a greater likelihood that the Division spent a longer amount of time and thus resources investigating the firm. Second, I capture the DCF's resources by measuring the number of rounds (Rounds) during the comment letter conversation. I measure the rounds as the number of times the SEC and client go back and forth discussing comment letter issues. In untabulated analysis, I also use the duration of the comment letter case as a proxy for the amount of resources spent on the case. The duration is measured as the length of the comment letter conversation from the date of the first comment letter to the date of the closing letter indicating all issues have been satisfactorily resolved. I conjecture that if it takes more time to resolve the comment letter issues, then the DCF likely spent more resources on the case. ${ }^{10}$

To test H2, I divide the primary sample into three subsamples based on the amount of resources allocated to the case (i.e. Issues or Rounds). Firms receiving the top 30\% of DCF resources make up the first subsample followed by firms with the middle $40 \%$ of resources in the second subsample, and firms with the bottom $30 \%$ of resources in the third subsample. As in testing H1, within each subsample, each comment letter firm is matched to a non-recipient with similar operating earnings that resides in the same industry. I estimate Equation 1 using each subsample and compare the magnitude of the $\alpha_{8}$ coefficients across each of the subsamples. I expect $\alpha_{8}$ to be the smallest for the subsample of firms receiving the most resources (i.e. time spent on comment letter case). This finding would provide support for the conjecture that the

\footnotetext{
${ }^{10}$ It could be argued that certain comment letter issues (revenue recognition or debt) may be more serious and issue type could be used as a measure of the severity to proxy for the amount of resources utilized by the DCF. However, each comment letter discuses an average of 15 issues, making it very difficult to come up with a meaningful method of sorting comment letters by issue. For instance, one comment letter could discuss revenue recognition, executive compensation and debt whereas another comment letter could discuss revenue recognition, fair value measurement, segment disclosures, critical accounting policies and estimates, and related party transactions.
} 
DCF purposefully spends more resources on firms with the poorest disclosure quality. Together these tests will provide evidence whether the DCF is selecting and allocating resources towards firms with poor disclosure quality. 


\section{DATA AND DESCRIPTIVE STATISTICS}

To test my hypotheses, I utilize comment letter and response data from the Audit Analytics database. The database covers all comment and response letters that the SEC has made publicly available on the SEC EDGAR website. I examine cases starting after December 31, 2004 and ending before January 1, 2010. For this period, I identify 18,301 cases $^{11}$. I remove 581 cases that did not have a SIC code for DCF Office categorization. While the SEC or firm can initiate a case, I focus the analyses on SEC initiated cases and therefore eliminate 1,654 non-SEC initiated cases ${ }^{12}$. Interestingly, there are 2,113 incomplete cases, where the SEC issued a comment letter but a firm response letter does not exist. I eliminate these cases given that it is unclear whether they represent missing response letters or nonresponsive firms. ${ }^{13}$ Because my analysis is focused on financial reporting disclosures, I eliminate 9,927 cases that do not relate to the SEC 10K and/or 10Q filings. Finally, the FERC analysis requires firms to have three years of consecutive earnings data and two years of consecutive returns data. Restricting cases to firms with data available on COMPUSTAT and CRSP further reduces the sample to 408 cases. A breakdown of the sample selection process is provided in Table 1.

\section{[TABLE 1]}

\footnotetext{
${ }^{11}$ Many cases coded in Audit Analytics overlap in time or occur within a short period of time from one another. It is likely that the latter case constitutes a continuation of the former case. With respect to all statistics reported in this study, I group cases that overlap or occur within 180 days of one another. This method is also adopted in Chen and Johnston (2010).

${ }^{12}$ This unique sample of firms that initiate contact with the SEC may be an interesting area to explore for future research.

${ }^{13}$ The representatives at Audit Analytics commented that all comment letters filed between 2005 and 2009 are coded in the database.
} 
Each comment letter recipient is matched to a non-recipient based on operating income, year, and 3-digit SIC industry code. Matching based on operating income is an essential control given that large firms have higher disclosure quality than small firms (Lang and Lundholm 1993) and the returns of large firms impound earnings news faster than those of small firms as a result of a richer information environment (Freeman 1987; Collins et al 1987; Collins and Kothari 1989). Matching based on operating earnings should also control for differences in the comment letter process due to firm size. Matching on operating earnings is important because the DCF maintains greater surveillance of larger firms (SEC Audit Report 2006). Lastly, matching on operating earnings helps control for differences in conservatism. Basu (1997) shows that bad news is impounded into earnings faster than good news and bad news firms have more variable earnings than good news firms. When matching on operating income, I require the income of the comment letter recipient be within ten percent of the income of the non-recipient and eliminate any match where the difference is greater than the requirement. As an additional precaution I use a discreet match to separately match loss firms to loss firms and income firms to income firms. Matching loss firms receiving a comment letter with loss firms not subject to a comment letter should control for differences in the FERC of loss firms and income firms. Matching by year eliminates any temporal factors that affect the returns and earnings association. Finally, matching based on industry controls for differences in the comment letter selection and review process across the twelve DCF offices. It also controls for any industry factors, such as business complexity, that may affect the relation between current returns and future earnings (FERCs).

Table 2 compares descriptive statistics for the comment letter recipients to the matched non-recipients. Panel A compares the comment letter recipients to their matched non-comment letter recipient on size, sales, age, book market ratio, leverage, discretionary accruals, unexpected 
earnings, market adjusted return. Significant differences were detected between the two groups related to age, leverage and market adjusted return. Comment letter recipients are significantly larger, less leveraged and have a higher market adjusted return than non-recipients. ${ }^{14}$ The DCF uses the criteria in the Sarbanes-Oxley Act to identify firms with high risk. One of the criteria is abnormally high stock returns which results in comment letter firms having a higher marketadjusted stock return than non-comment letter firms. The two groups are similar in terms of market value, size, sales, book to market ratio, discretionary accruals, and unexpected earnings. Finally, Panel B provides comparisons for variables used in the severity analysis. The DCF identifies 15 issues on average for comment letter recipients. The DCF and firm go back and forth approximately 5 times (rounds) before the issues are successfully resolved.

[TABLE 2]

\footnotetext{
${ }^{14}$ The impact of differences in size and leverage are investigated in the section 7.1.
} 


\section{RESULTS}

To compare the FERC of comment letter recipients to non-recipients Equation 1 is estimated using ordinary least squares regression. To control for heteroscedasticity, p-values are reported using robust standard errors and clustered across time (Peterson 2009). Table 3 presents Spearman/Pearson correlations for all variables used to estimate equation 1 . None of the reported correlations suggest problems with multicollinearity.

\section{[TABLE 3]}

\subsection{Testing H1}

Results for the FERC analysis (Equation 1) are reported in Table 4. Results are reported with and without influential observations. ${ }^{15}$ All variance inflation factors (VIFs) are less than two indicating that multicollinearity is not a problem. The FERC (Contemporaneous ERC) represented for the non-recipient sample is captured in $\alpha_{3}\left(\alpha_{2}\right)$. Although I did not posit a formal hypothesis with respect to contemporaneous ERCs, the results are consistent with comment letter firms having lower quality earnings. The coefficient, $\alpha_{7}$, which captures the differential ERC between the two groups, is negative and highly significant $(\mathrm{p}<.01$ two-tailed t-test). The result is consistent with the DCF successfully utilizing SOX criteria to target firms with poor earnings quality.

As predicted the results are also consistent with comment letter firms having lower FERCs. The coefficient, $\alpha_{8}$, which captures the differential FERC between the comment letter recipients and non-recipients is significantly negative $(\mathrm{p}<.01$ two-tailed $\mathrm{t}$-test $)$. This result is

\footnotetext{
${ }^{15}$ Influential observations are identified using Cook's D (Cook 1977). I eliminate influential observations where D > 4 / $\mathrm{n}$ (where $\mathrm{n}$ is the sample size) (Bollen and Jackman 1990).
} 
consistent with comment letter recipients having lower disclosure quality than non-recipients. All other coefficient estimates follow their predicted signs or are insignificant.

\section{[TABLE 4]}

The descriptive statistics reported in Table 2 show significant differences in size (Size) and Leverage (Lev) between the comment letter recipient and non-recipient samples. To insure that these differences are not affecting the results, I expand equation 1 to include both control variables. The results are reported in Table 5 and are consistent with the findings presented in Table 4. Overall, the findings are consistent with the conjecture that the DCF is successful in targeting firms which investors perceive to have low quality earnings (low ERCs) and low quality disclosures (low FERCs).

\section{[TABLE 5]}

\subsection{Testing $\mathrm{H} 2$}

The second hypothesis, $\mathrm{H} 2$, predicts that the SEC will allocate more resources towards firms the market perceives as having significantly lower disclosure quality. To test H2 I utilize the number of rounds identified by the DCF as a proxy for the amount of resources allocated to a specific comment letter case. The sample is divided into two groups (LOW and HIGH) based on the number of rounds identified by the DCF. For each group, I identified a matched pair for each observation based on operating earnings and utilized this sample to estimate Equation 1. To test whether ERCs and FERCs are significantly smaller for firms where the DCF allocates more resources I modify Equation 1 by including an indicator, HIGH, which is one if the firm falls in 
the top 30 percent of comment letter firms based on DCF resource allocation; 0 otherwise. I interact these variables with the other independent variables in Equation 1 as follows:

$$
\begin{aligned}
& \text { MAR }_{t}=\alpha_{0}+\alpha_{1} \Delta E_{t-1}+\alpha_{2} \Delta E_{t}+\alpha_{3} \Delta E_{t+1}+\alpha_{4} M_{A R} R_{t+1}+\alpha_{5} C L_{t+1}+\alpha_{6} H_{G G H_{t+1}} \\
& +\alpha_{7} \Delta E_{t-1} * C L_{t+1}+\alpha_{8} \Delta E_{t} * C L_{t+1}+\alpha_{9} \Delta E_{t+1} * C L_{t+1}+\alpha_{10} M_{t+1} * C L_{t+1} \\
& +\alpha_{11} \Delta E_{t-1} * C L_{t+1} * H I G H_{t+1}+\alpha_{12} \Delta E_{t} * C L_{t+1} * H I G H_{t+1}+\alpha_{13} \Delta E_{t+1} * C L_{t+1} * H I G H_{t+1} \\
& +\alpha_{14} \text { MAR }_{t+1} * C L_{t+1} * H_{t+1}+\varepsilon_{t}
\end{aligned}
$$

The three-way interactions show how ERCs and FERCs for firms with the most severe comment letter cases compare with firms where the DCF allocated fewer resources (i.e. Low group). I expect negative coefficients on these ERC and FERC three way interaction variables (i.e. $\left.\Delta E_{t} * C L_{t+1} * H I G H_{+1}, \Delta E_{t+1} * C L_{t+1} * H I G H_{+1}\right)$. The results are shown in Table 6 and results do not provide any support for hypothesis 2 .

\section{[TABLE 6]}

I also try using the number of issues identified by the DCF, the number of abnormal issues unrelated to the size of the firm, the DCF office that reviewed the case ${ }^{16}$, and duration of the comment letter case (measured in days) as proxies for resource allocation. The results continue to lack significance for these alternate proxies for resource allocation.

Overall, the results indicate that comment letter recipients have significantly lower forward earnings response coefficients than non-comment letter recipients. This finding is consistent with the conjecture that the DCF is effective in selecting firms that are perceived to have low disclosure quality. Secondly, the results document that comment letter firms have significantly lower contemporaneous ERCs than non-recipients which is consistent with the DCF using SOX criteria to target firms with poor earnings quality. Yet, within comment letter

\footnotetext{
${ }^{16}$ Abnormal comment letter issues are calculated as the residual of a model where I regress \# of issues on firm size (measured as the log of total assets) and DCF office. The abnormal issues variable captures issues that are unrelated to the size of the firm or the DCF office that reviewed the case.
} 
firms, I am unable to provide any evidence that the DCF allocates more resources to firms with lower contemporaneous or forward earnings response coefficients. 


\section{CONCLUSION}

The goal of the SEC is to enhance the quality of information available to investors for making informed investment decisions; however, little is known about the Commission's process of selectively commenting on filings. The SEC's Division of Corporate Finance plays a large role in the U.S. financial reporting system and is responsible for monitoring all public companies. The Division carries out its mission operating under a budget of approximately $10 \%$ of the SEC's resources which is a miniscule amount compared to the budgets of other monitors. Given that Congress recently froze the SEC's budget, the Division's monitoring actions may become even more constrained. I contribute to literature on the SEC's role as a monitor by investigating how effectively the Division identifies and allocates resources to comment letter recipients.

I extend prior research by investigating the disclosure quality of comment letter recipients in the period between 2005 and 2010. My sample includes firms receiving comment letters related to their $10 \mathrm{~K} / 10 \mathrm{Q}$. I focus on comment letters related to this sample because the DCF reviews the $10 \mathrm{~K} / 10 \mathrm{Q}$ as part of its preliminary review to decide if further review of the firm is warranted. Following prior research, I use forward earnings response coefficients to measure the differential informativeness of stock returns (FERC) (Gelb and Zarowin 2002; Lundholm and Myers 2002). I hypothesize that comment letter recipients' stock returns will be less informative about future earnings (lower FERC). Results indicate that comment letter recipients have less informative disclosures. Finally, results document that comment letter recipients also have lower contemporaneous ERCs. Overall, results provide support for the conjecture that the DCF successfully targets firms with poor financial reporting quality. . 
My study extends prior research that primarily focuses on the market effects of receiving a SEC comment letter. However, my study is not without limitations. I utilize comment letters within a small time frame which inhibits the generalizability of my results. I also solely focus on comment letters related to firms' $10 \mathrm{~K}$ or $10 \mathrm{Q}$. Finally, my study relies solely on the FERC as a proxy for disclosure quality. Future research could explore comment letters related to other filings and utilize different measures to gauge the disclosure quality of comment letter recipients such as bid-ask spread. Studies could also further explore ensuing market consequences in order to gauge whether the DCF office is adding value. Market evidence can contribute to the policy debate concerning benefits of public monitoring and enforcement. Overall, the publically available SEC comment letters are a rich and unexplored area of accounting. 


\section{REFERENCES}

Basu, S. (1997). "The Conservatism Principle and the Asymmetric Timeliness of Earnings." Journal of Accounting and Economics 24, 3-37.

Beatty, R.P., Bunsis, H., and J.R. Hand, 1998. The indirect economic penalties in SEC investigations of underwriters. Journal of Financial Economics 50, 151-186.

Beneish, M., 1999. Incentives and Penalties Related to Earnings Overstatement That Violate GAAP. The Accounting Review 74 (4): 425-457

Bollen, K.A. and Robert Jackman. 1990. "Regression Diagnostics: An Expository Treatment of Outliers and Influential Cases." Pages 257-291 in J. Fox and J. Scott Long (eds.) Modern Methods of Data Analysis. Newbury Park, CA: Sage.

Chen. R., and R. Johnston. 2010. Securities and exchange commission comment letters: Enforcing accounting quality and disclosure. The Ohio State University working paper.

Collins, D. W., and S. P. Kothari. 1989. An analysis of intertemporal and cross-sectional determinants of earnings response coefficient. Journal of Accounting and Economics 11 (July): 143-181.

Collins, D.W., S.P. Kothari, J. Shanken, and R. Sloan. 1994. Lack of timeliness and noise as explanations for the low contemporaneous return-earnings association. Journal of Accounting and Economics: 18:289-324.

Cook, R. Dennis (Feb 1977). "Detection of Influential Observations in Linear Regression". Technometrics (American Statistical Association) 19 (1): 15-18.

Dechow, P., R. Sloan and A. Sweeney, 1996. Causes and Consequences of Earnings Manipulation: An Analysis of Firms Subject to Enforcement Actions by the SEC. Contemporary Accounting Research 13 (1): 1-36

Ertimur, Y., and M.E. Nondorf, 2008. The SEC comment letter process and its effects on the quality of disclosure for IPO firms. Working Paper, Duke University.

Fama, Eugene F., and Kenneth R. French. "Industry costs of equity." Journal of Financial Economics 43 (1997): 153-193.

Farber. 2005. Restoring Trust after Fraud: Does Corporate Governance Matter? The Accounting Review 80 (2): 539-561

Feroz, E., Park, K., and V. Pastena, 1991. The financial and market effects of the SEC's Accounting and Auditing Enforcement Releases. Journal of Accounting Research. 
Gao, L., Lawrence, J. and David Smith. 2010. SEC comment letters and financial statement restatements. Working paper: The University of Nebraska.

Gelb and Zarowin 2002. Corporate disclosure policy and the informativeness of stock prices. Review of Accounting Studies 7(1):33-52.

Lang, M. and R. Lundholm. 1993. Cross sectional determinants of analyst ratings of corporate disclosures. Journal of Accounting Research. 31(2): 246-271.

Lang, M. and R. Lundholm. 1996. Corporate disclosure policy and analyst behavior. The Accounting Review 71 (October): 467-492.

Lundholm, R., and L. Myers. 2002. Bringing the future forward: The effect of disclosure on the returns-earnings relation. Journal of Accounting Research 40 (3): 809-839.

Sarbanes Oxley Act of 2002: http://www.sec.gov/about/laws/soa2002.pdf.

Securitites and Exchange Commission, Annual Report (2003): http://www.sec.gov/about/annrep03.shtml

Securitites and Exchange Commission, Audit Report (2006), \#401: http://www.secoig.gov/Reports/AuditsInspections/2006/401fin.pdf

Sengupta, P. 1998. Corporate disclosure quality and the cost of debt. The Accounting Review. 73 (4): 459-474.

Welker, M. 1995. Disclosure policy, information asymmetry and liquidity in equity markets. Contemporary Accounting Research 11 (Spring): 801-827. 


\section{APPENDIX: Comment Letter Descriptive Analysis}

The DCF comments on a wide range of accounting and disclosure related issues. Secondly there are also differences between the DCF offices related to the number of firms, cases, and comment letters. For the 2005 to 2009 period DCF offices commented on 1,160 unique issues as coded by Audit Analytics. These issues can be categorized into seven broad categories: 1) Accounting Standards related to U.S. GAAP (589 issues); 2) Accounting Standards related to IFRS (210 issues); 3) Operational, Controls \& Risk Assessment (69 issues); 4) Securities Regulations (186 issues); 5) New and Secondary Registrations (73); 6) Mergers \& Acquisitions (18 issues); and 6) Non-Standard and Other Disclosures (33) issues. Audit Analytics further divides these primary categories into twenty-five sub-categories. The subcategories are defined in Table 7.

\section{[TABLE 7]}

I divide the data across DCF office because a recent DCF audit report points out that each office has the power to act independently and exercise its own expertise when deciding on the type of review. The DCF offices initiating the most comment letter cases include Office 4Natural Resources and Food, Office 10- Electronics and Machinery and Office 6 -Manufacturing and Construction. The least represented DCF offices include Office 23-Business Services, Office 9- Beverages, Apparel, and Health Care Services, and Office 2 Consumer Products (See Table 8, Panel A). Additionally, there is variability in the number of cases each office initiates with Office 4 representing $11 \%$ of the total communication from the SEC and Office 23 only representing 3\%. Next, Panel A reports the number of unique issues each DCF office identified during its dialogue with firms. It is interesting that the offices initiating the most comment letter cases $(4,6$, and 11) also discover the largest number of unique issues. Therefore, not only are 
these offices sending more comment letters but they are also identifying more distinctive problem areas. This finding could indicate that offices 4,6 , and 11 perform a more exhaustive review.

Table 8, Panel B documents the communication process between the DCF and firms. First, the panel points out the firm's initial response time which indicates how long it took the firm to respond to the SEC's first comment letter. The fastest and slowest response time are approximately 17 days and 50 days with the average being 28 days. The average initial response time seems abnormally high considering that the SEC requires firms to respond to the initial comment letter within 10 days ${ }^{17}$. If a firm cannot articulate a written response within 10 days, it is required to call the Division and indicate how much time is needed to address the comment letter issues. It is possible that some firms initially responded to the SEC by phone prior to the ten day requirement to request a delay; however, there is no record of firm responses by phone. As mentioned previously, the correspondence between the DCF and firm can go back and forth several times. Table 8, Panel B indicates that the DCF and firm engage in an average of 6 rounds of communication prior to resolving the issues. There is minimal variability between DCF offices regarding the number of rounds, with every office engaging in 5 or 6 rounds. Finally, on average it takes approximately 66 days to resolve the comment letter case. The comment letter resolution rate could be attributed to either the speed of the staff or the responding firm or both. DCF office 4-Natural Foods and Services has the slowest comment letter resolution rate of 77 days. The fastest comment letter resolution rate is 59 days for Office 7-Financial Services.

\section{[TABLE 8]}

\footnotetext{
${ }^{17}$ I calculate the initial response time in number of days using the variable event date on Audit Analytics.
} 
To get an idea of where the DCF is focusing its attention the frequency of comment letter cases by the 25 sub-categories is presented with a pie-chart in Figure 3. The chart shows the top 9 sub-categories and groups the remaining 16 sub-categories into a category called Other. The primary focus of the DCF is general accounting and disclosure mostly related to U.S. GAAP ( $20 \%$ of cases deal with these issues). Registration statements are also a top area with $15 \%$ of all comment letters dealing with these issues. It is not surprising that so many comment letter cases deal with registration statements given that it is mandatory for the DCF to review all of these statements. Other areas that are of great interest to the DCF are SFAS standards (12\%), Regulation SK (10\%), MD\&A (6\%), Risk Factors (4\%), Regulation SX (4\%), Event Disclosures (3\%), and Emerging Issues Task Force (EITF) (2\%). ${ }^{18}$

\section{[FIGURE 3]}

It is also possible to analyze comment letters across the different SEC filings. Figure 4 presents a pie chart with the frequencies of comment letters by filing type for the period 20052009. The different filing types are defined in Table 9. During this time period, the DCF commented on 99 different filings. The top ten filings receiving comments from the SEC are shown in Figure 4 and include the 10-K, 10-Q, 10KSB ${ }^{19}, 8-\mathrm{K}, 10 \mathrm{QSB}$, DEF14A, 10K-A, $10 \mathrm{KSB} / \mathrm{A}, \mathrm{S}-1 / \mathrm{A}$, and the $20-\mathrm{F}$. Given that the SEC periodically reviews filings starting with the annual report; it is not surprising for various versions of this filing to represent $72 \%$ of all the filings receiving comment letters. The SEC also frequently comments on the following forms: 8$\mathrm{K}$, DEF $14 \mathrm{~A}, \mathrm{~S}-1 / \mathrm{A}$ and $20-\mathrm{F}$. It is not surprising that DEF $14 \mathrm{~A}$ and S-1/A receive a large number of comments from the SEC since both filing types are always reviewed at submission.

\footnotetext{
${ }^{18}$ It is important to note that these categories are not mutually exclusive to particular comment letter cases, meaning a comment letter case can deal with multiple categories (i.e. SFAS standard, MD\&A, and Risk Factors).

${ }^{19}$ This form will no longer be used after March 16, 2009, although existing filings will remain in the SEC's EDGAR system.
} 
However, it is curious that the SEC initiates more comment letters related to amendments of firms' registration statement (S-1/A) than the original form S-1.

[FIGURE 4]

[TABLE 9]

Top Issues by Category

In order to determine the type of issues that the DCF is focused on, I calculate the frequency of comment letter cases for each of the twenty five sub-categories. The Audit Analytics database is organized in a manner that allows the user to tie specific issues to a specific category but not to a specific SEC filing. Top 5 issues related to the top 9 sub-categories are reported in Table 10. The number one GAAP issue is revenue recognition. It is interesting that revenue recognition is commonly detected by the DCF offices in SEC comment letters and it is also the most frequent driver of accounting restatements identified by auditors. In terms of accounting and disclosure issues, the SEC also identifies issues dealing with intangibles/goodwill, derivatives, revenue, and debt as cited by the FASB and EITF. Other main areas of focus include the MD\&A section, risk factors, and 8-K event disclosures. It is interesting that filers have difficulty implementing both old and new standards. For instance, SFAS 142Goodwill/Intangibles and SFAS 123 R- Stock options are more recent standards issued in the early/mid 2000s. It could be expected that firms would experience difficulty adjusting to these new guidelines which could account for the numerous comments from the SEC. However, SFAS 95 - Cash flow statement, SFAS131- Segment disclosures and SFAS 133- Derivatives had existed for at least 7 years prior to the date of the comment letters reviewed in this study and the SEC continues to comment frequently on each one. 


\section{[TABLE 10]}

Top Issues by Year

Next I break issues down by year during the period 2005-2009. The results are displayed in Table 11. It is interesting to note that most of the issues are in the top three for at least two years. For example, debt, quasi-debt, warrants \& equity is the number one issue in both 2005 and 2006 and continues to be of great interest in 2007 as the number two issue. Filers also appear to have difficulty reporting revenue throughout the time period because revenue recognition is the second most common issue in 2005 and 2006 then drops to number three in 2007. Other issues such as executive compensation plan disclosure, signatures/exhibits/agreements, and disclosure control reporting all place in the top three twice. Identifying certain issues should not be surprising given the SEC's recent initiative. For instance, issues related to executive compensation disclosures make sense given that new executive compensation rules went into effect in 2006. It is evident that the SEC is committed to executive compensation given the rule change and the fact that the SEC sent 350 comment letters to public companies regarding this topic to determine how well companies were adapting to the new guidelines. Overall, the SEC voiced that better disclosure was needed on how and why compensation policies were designed. The persistence of top issues indicates that these issues are pervasive among filers and appear to be difficult problem areas to correct based on their tendency to reemerge. On the other hand, a few issues are only listed in a single year. Acquisitions, mergers, and business combinations is the number three issue in 2006 and Regulation S-K, Item 601 (Exhibits) is number three in 2009.

[TABLE 11] 
Top Issues by DCF Office

Table 12 reports the most frequent issues by DCF Office. Even though DCF offices are industry specific, certain issues appear in the top three for the majority of offices. For instance, $75 \%$ of the DCF offices report debt, quasi-debt, warrants \& equity as one of their top three issues. Filers frequently receive comments on this issue because the DCF requests further disclosure concerning debt classification, provisions, restrictions and modifications.

Signatures/agreements/exhibits (SAE) and revenue recognition are also frequent topics and consistently fall in the top 3 issues for at least five of the offices. Related to the first topics, filers may be missing a signature or other necessary piece of the registration statement. Finally, it is interesting that four of the offices regularly have problems with the issue of disclosure control and reporting which most often indicates that firms did not use the proper definition of disclosure controls and procedures or omitted necessary language when drawing conclusions. Although the SEC grants each DCF office authority to independently structure its review process, the offices appear to reach similar conclusions regarding certain problematic areas.

[Table 12]

Issue Comparison of Small vs. Large Filers- Analysis of 10-K

Based on prior analysis, it is remarkable that the third most frequent filing discussed in comment letter cases is the $10 \mathrm{KSB}$ with the $10 \mathrm{QSB}$ also placing in the top ten. Since such a large number of filings specific to small businesses receive comment letters (See filings ending in SB in Figure 3), it is interesting to explore differences between the issues identified for small and large businesses. Unfortunately, there is only a small business filing for the $10 \mathrm{~K}$ and $10 \mathrm{Q}$ and not other filings. Therefore, in order to make a comparison, I examine differences between 
comment letter cases referring to $10 \mathrm{~K} / 10 \mathrm{Q}$ filings and comment letter cases referring to 10KSB/10QSB filings ${ }^{20}$.

Table 13 documents the top three issues by DCF office for large and small filers. For large filers, exhibit disclosures (Regulation S-K Item 601) is the most frequently discussed issue, placing in the top three for nine offices. Related to this issue, the SEC often requests filers to provide proper, complete disclosure in exhibits accompanying financial statements. Despite the attention on disclosure, there is a large amount of variation in the other top issues for large firms. The DCF offices also frequently comment on executive compensation disclosure (Regulation S$\mathrm{K}$, Item 402), revenue recognition, PPE-intangible assets and goodwill and MDA disclosures (Regulation S-K, Item 303). On the other hand, the SEC appears to comment the most on issues involving disclosure control reporting and debt, quasi-debt, warrants and equity. These issues appear in the top three for at least nine offices. It is interesting that the small filers have difficulty with unique issues. Unlike large filers, it appears that small filers have trouble with internal control disclosures and liabilities, payables, and accrual estimates. Overall, the fact that there are different issues based on firm size provides some evidence that the DCF offices have a fluid selection and review process and adapt to characteristics of the filer.

[TABLE 13]

\section{Characteristics of Firms Receiving Comment Letter}

To provide insight into the type of firms receiving a comment letter from the DCF, I provide basic descriptive statistics related to firm performance, risk, earnings quality, and value for filers receiving a comment letter from the DCF. Each statistic is calculated using a subsample

\footnotetext{
${ }^{20}$ Firms with less than $\$ 10$ million in assets and whose securities are held by fewer than 500 owners had the option of filing Form 10-KSB instead of 10-K until March 16, 2009.
} 
of the comment letter sample, restricted by data availability on COMPUSTAT and CRSP. For comparative purposes, I also calculate the industry adjusted means by matching each firm to its Fama and French (1997) industry classification as follows: ${ }^{21}$

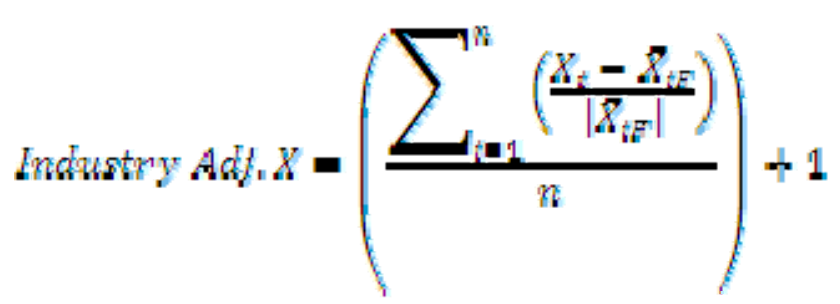

Where $\mathrm{X}$ is the descriptive variable of interest (i.e. Size, Age, etc.) for firm i within the comment letter sample and $\tilde{X}_{t \bar{F}}$ is firm i's matched Fama French industry average. The industry adjusted mean provides an interpretable statistic of how comment letter firms differ from the average firm within their respective industries.

Descriptive statistics related to the entire comment letter sample are provided in Table 14. Panel A shows that comment letter firms are twenty-four percent larger and four percent older (Industry Adjusted means of 1.24 and 1.04 respectively) than the typical firm within their respective industries. Panel B provides means related to firm performance. Comment letter firms perform better (Industry Adjusted ROA 1.09), have stronger future growth expectations (Industry Adjusted Book-to-Market of 0.85), and make up a higher percentage of industry revenues (Industry Adjusted Industry Revenue of 1.17) than average firms within their respective industries. Panel C indicates that comment letter firms are similarly leveraged (Industry Adjusted Leverage of 0.98 ) and have nearly identical interest coverage ratios (Industry Adjusted Interest Coverage of 1.00) as the average industry firm.

Panel D investigates the earnings quality of comment letter firms. I calculate the absolute level of discretionary accruals as a proxy for earnings quality. I utilize four different accrual

\footnotetext{
${ }^{21}$ Fama and French (1997) divide firms into 44 industry groupings.
} 
estimation models to estimate discretionary accruals including: the Modified Jones model, the Adjusted Jones model, the Lagged Jones model and the Forward-looking Jones. ${ }^{22}$ All models indicate that comment letter firms have higher accrual estimation errors (i.e. indication of more discretionary accruals) than industry peers; however, the difference is very small for the more sophisticated forward looking model (Industry Adjusted Abs. Forward Jones 1.01). Comment letter firms also have similar earning and cash flow volatility (Industry Adjusted Std. EPS 1.02 and CFPS 0.97) when compared to the industry average. The only indication that comment letter firms have lower earning quality is they experience a slightly higher number of restatements when compared to other firms within their industry (Industry Adjusted Restatement 1.04). Finally, descriptive statistics in Panel E indicate that these firms have a higher PE ratio (Industry Adjusted PE 1.08) and are less volatile (Industry Adjusted Share Price Volatility 0.93) than the average firm within their industry.

\section{[TABLE 14]}

As previously discussed, there are several reasons the DCF could select a firm for review. First, the DCF could pick a firm because it has not been reviewed in the past two years; therefore, it must be reviewed in the current year. Second, firms should be selected when they meet SOX criteria. Finally, specific filings are always reviewed upon submission (i.e. mandatory review). To get a better understanding of the characteristics of firms identified by the SarbanesOxley Act criteria, I limit the sample to $10 \mathrm{~K}$ and $10 Q$ filings $^{23}$ which are not subject to mandatory reviews. Limiting the sample to $10 \mathrm{~K}$ and $10 \mathrm{Q}$ filings provides a noisy selection of firms that are more likely to be targeted based on the Sarbanes Oxley Act criteria for review. Descriptive statistics related to these firms are provided in Table 15. Panel A shows that these

\footnotetext{
${ }^{22}$ See Dechow et al. 2003 for a detailed description of the estimation models.

${ }^{23}$ Includes 10K, 10Q, 10KSB, 10QSB, 10KNT, 10QNT, 10KSBNT, and 10QSBNT filings.
} 
firms are considerably larger and older (Industry Adjusted means of 1.21 and 1.23 respectively) than the average industry firm. Panel B provides descriptive statistics related to firm performance. These firms perform much better (Industry Adjusted ROA 4.68) and have stronger future growth expectations (Industry Adjusted Book-to-Market of 0.61). Panel C indicates that comment letter firms are less leveraged (Industry Adjusted Leverage of 0.73 ) than other firms within their industries and have larger interest coverage ratios (Industry Adjusted Interest Coverage of 1.72). Panel D investigates the earnings quality of comment letter firms. These firms have smaller accrual estimation errors, less volatility in earnings (Industry Adjusted Std. EPS 0.92), and less volatile cash flows (Industry Adjusted Std. CFPS 0.46) than the average firm within their respective industries. The firms also experience a similar number of restatements compared to the industry average (Industry Adjusted Restatement 0.97). Finally, descriptive statistics in Panel E indicate that these firms have similar PE ratios (Industry Adjusted PE 1.26) and experience less market volatility (Industry Adjusted Share Price Volatility of 0.47) than the average firm within their respective industries. Overall, firms receiving a comment letter with respect to their $10 \mathrm{~K}$ or $10 \mathrm{Q}$ filing are large, growth firms. The descriptive statistics indicate that these firms do not have lower quality earnings, or more volatile stock prices which is consistent with the SEC targeting industry leaders but not necessarily firms with poor information environments. The descriptive statistics are consistent with the DCFs 2006 Audit report that mentioned the DCF was only targeting firms that affect a material sector of the economy and ignoring the remaining Sarbanes Oxley criteria.

[TABLE 15]

Using the 10K / 10Q sample, I present Spearman correlation coefficients for two of the most common issues; 1) Revenue Recognition and 2) Debt, quasi-debt, warrants \& equity (BCF) 
security and firm characteristics in Table 16. The correlations vary between offices. Revenue recognition is negatively correlated with firm size indicating that smaller firms seem to have more difficulty accounting for revenue. Also, revenue is negatively correlated with book to market which indicates that firms experiencing more growth also have more revenue recognition issues. For the majority of offices, the issue related to debt, quasi-debt, warrants and equity is significantly correlated with leverage. Therefore, firms with greater leverage receive more comment letters related to debt issues. Also, there is a negative correlation between debt issues and interest coverage. The smaller interest coverage ratio indicates that these firms have a large amount of interest relative to their earnings. Return on assets is negatively correlated with debt issues for several offices and may indicate that the DCF comments on poor performing firms. Overall, the DCF seems to comment on debt related issues for firms that are highly leveraged, poor performers, and have large interest payments relative to their earnings.

[TABLE 16] 


\section{Figure 1}

Division of Corporate Finance (DCF) Offices by Industry

\begin{tabular}{|l|l|}
\hline 1 & Health Care and Insurance \\
\hline 2 & Consumer Products \\
\hline 3 & Computers and Online Services \\
\hline 4 & Natural Resources and Food \\
\hline 5 & Structured Finance, Transportation, and Leisure \\
\hline 6 & Manufacturing and Construction \\
\hline 7 & Financial Services \\
\hline 8 & Real Estate and Business Services \\
\hline 9 & Beverages, Apparel, and Health Care Services \\
\hline 10 & Electronics and Machinery \\
\hline 11 & Telecommunications \\
\hline 23 & Business Services, NEC \\
\hline
\end{tabular}

The DCF assigns each filing to one of twelve offices based on the firms' SIC code. The staff in each office have specialized industry, accounting, and disclosure expertise. 
Figure 2

Timeline of Events

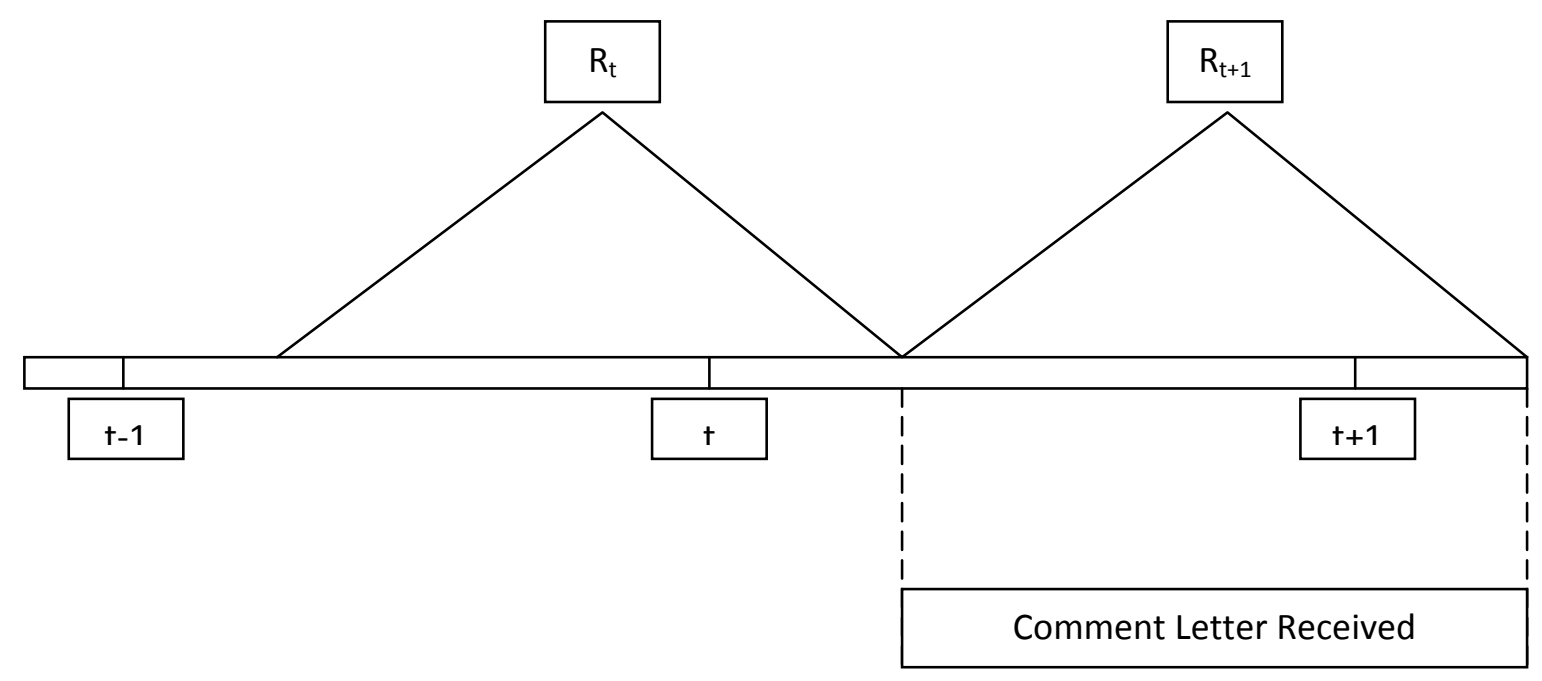

$\mathrm{R}$ represents the market adjusted Return.

$t-1, t$, and $t+1$, boxes are indicated at the end of year. 
Figure 3

Area of Comment Letter by Issue Category for 2005 to 2009

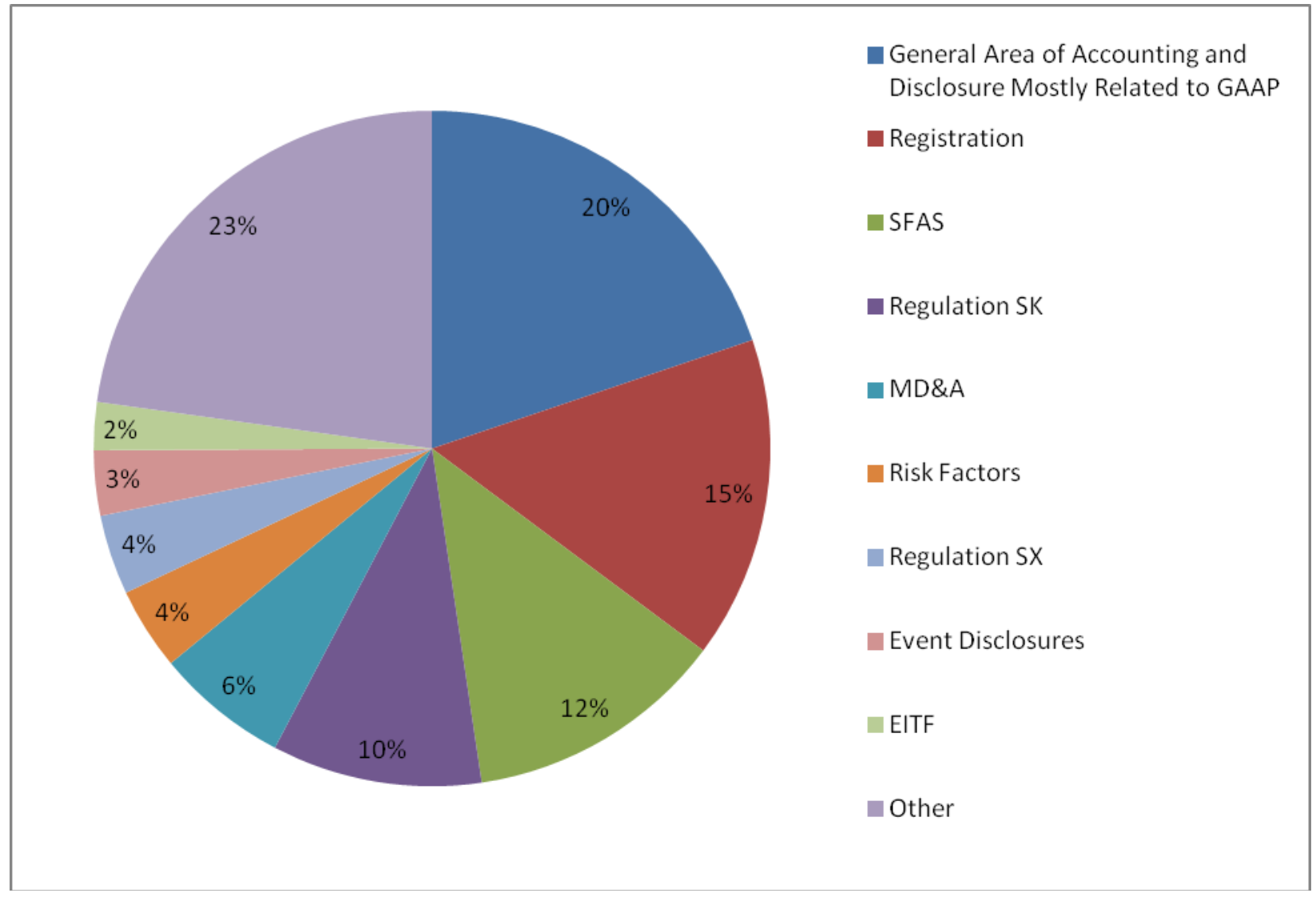


Figure 4

Area of Comment Letter Focus by Filing Type for 2005 to 2009

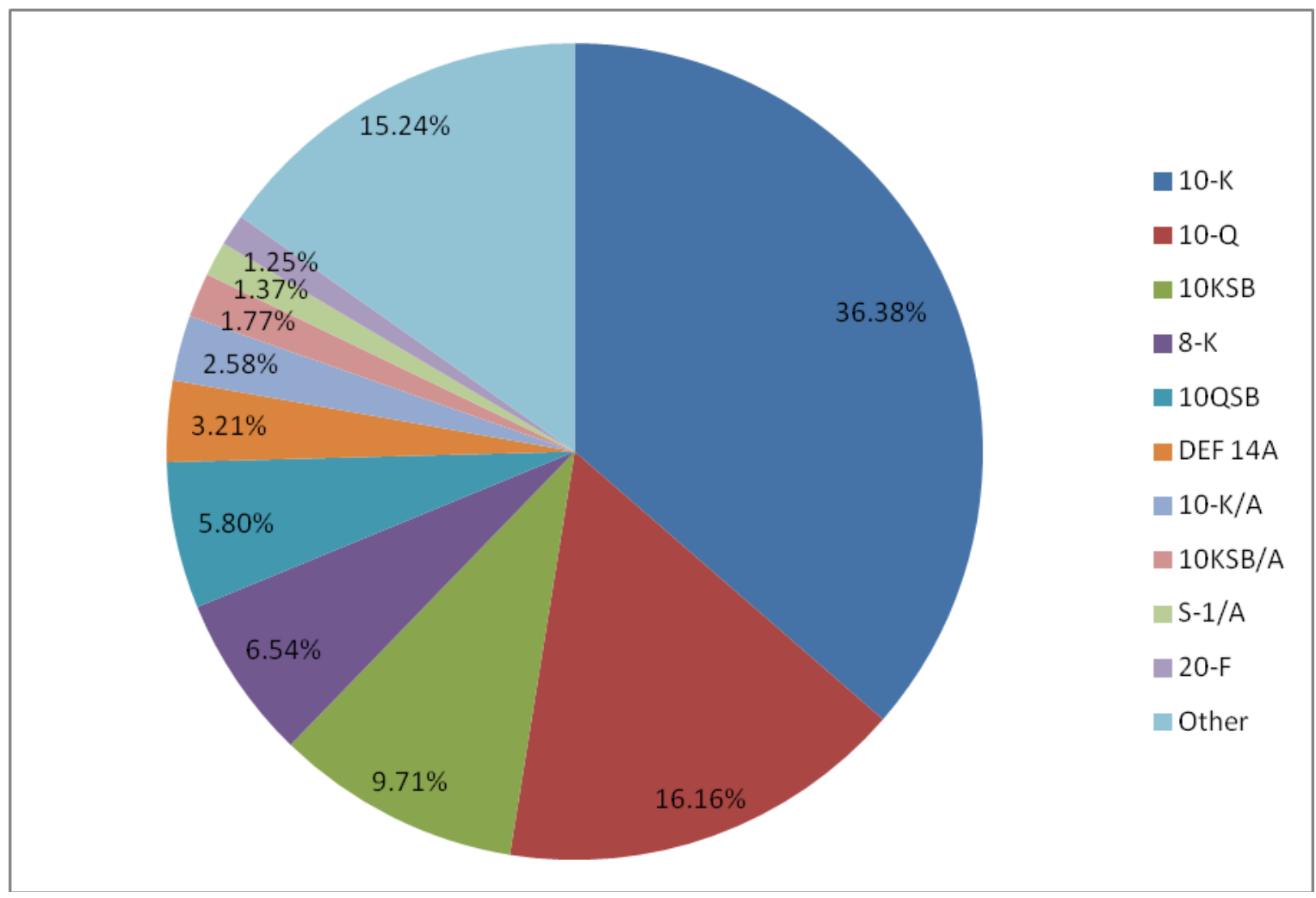




\section{Table 1}

Sample Selection Process Comment Letter Conversations

Cases and Letters Identified on Audit Analytics from 2005 to 2009

\begin{tabular}{c|} 
Conversations \\
\hline 18,301 \\
17,719 \\
16,066 \\
13,953 \\
4,026 \\
408 \\
\hline
\end{tabular}

Cases with SIC Code for DCF Office Categorization

Cases Initiated by SEC

Complete Cases

Cases Related to 10K / 10Q Filing

Cases with Data on COMPUSTAT and a Matched Pair

18,301

17,719

3,953

408 
Table 2

Descriptive Statistics CL Firms and Non-CL Firms

Panel A: Comparisons between Comment Letter Recipients and Non-Recepients

\begin{tabular}{llcccccc}
\hline \multirow{2}{*}{ Variable } & \multicolumn{1}{c}{ Recipient } & Mean & $\begin{array}{c}\text { Std. } \\
\text { Dev. }\end{array}$ & 25 th & Median & 75 th & Sig. \\
& Non-Recipient & 529.30 & 1060.00 & 108.40 & 203.10 & 456.90 & \\
& CL Recipient & 815.00 & 2511.00 & 101.10 & 246.80 & 585.90 & \\
\hline Size & Non-Recipient & 5.4651 & 1.7497 & 4.2813 & 5.1387 & 6.7671 & \\
& CL Recipient & 5.4967 & 1.8346 & 4.3701 & 5.2496 & 6.5604 & \\
\hline Sales & Non-Recipient & 345.98 & 1337.09 & 28.89 & 82.84 & 194.01 & \\
& CL Recipient & 359.41 & 1321.08 & 32.21 & 86.37 & 204.12 & \\
\hline Age & Non-Recipient & 11.0330 & 8.3517 & 6.1667 & 8.6667 & 12.4167 & $* *$ \\
& CL Recipient & 13.0927 & 9.9271 & 6.7500 & 9.8333 & 16.3333 & \\
\hline BookMkt Ratio & Non-Recipient & 0.7273 & 0.9917 & 0.1990 & 0.5161 & 0.8492 & \\
& CL Recipient & 0.6127 & 0.6647 & 0.2759 & 0.4668 & 0.7660 & \\
\hline Leverage & Non-Recipient & 0.1852 & 0.2678 & 0.0005 & 0.0712 & 0.2649 & \multirow{2}{*}{$* * *$} \\
& CL Recipient & 0.1204 & 0.1809 & 0.0000 & 0.0565 & 0.1787 & \\
\hline Discretionary Accruals & Non-Recipient & 0.3032 & 0.7645 & 0.0740 & 0.1550 & 0.2605 & \\
& CL Recipient & 0.2725 & 0.9550 & 0.0711 & 0.1407 & 0.2409 & \\
\hline UE & Non-Recipient & 0.0173 & 0.1793 & -0.0351 & 0.0043 & 0.0403 & \\
& CL Recipient & 0.0149 & 0.0850 & -0.0156 & 0.0063 & 0.0364 & \\
\hline MAR & Non-Recipient & 0.0995 & 1.1145 & -0.4250 & -0.1755 & 0.1725 & $* * *$ \\
& CL Recipient & 0.1651 & 0.7112 & -0.2537 & 0.0168 & 0.3296 & \\
\hline
\end{tabular}

Panel B: Comment Letter Recipients

\begin{tabular}{lccccc}
\hline & Mean & $\begin{array}{c}\text { Std. } \\
\text { Dev. }\end{array}$ & 25 th & Median & 75 th \\
\hline Rounds & 5.12 & 2.79 & 3 & 4 & 6 \\
\hline \# of Issues & 15.36 & 11.11 & 8 & 12 & 20 \\
\hline
\end{tabular}


Table 3

Pearson Correlation Coefficients

\begin{tabular}{|c|c|c|c|c|c|c|c|c|c|c|}
\hline & $\mathrm{MAR}_{\mathrm{t}}$ & $\mathrm{UE}_{\mathrm{t}-1}$ & $\mathrm{UE}_{\mathrm{t}}$ & $\mathrm{UE}_{\mathrm{t}+1}$ & $\mathrm{MAR}_{\mathrm{t}+1}$ & $\mathrm{CL}_{\mathrm{t}+1}$ & $\begin{array}{l}\mathrm{CL}_{\mathrm{t}+1} * \\
\mathrm{UE}_{\mathrm{t}-1}\end{array}$ & $\begin{array}{l}\mathrm{CL}_{\mathrm{t}+1} \\
\mathrm{UE}_{\mathrm{t}}\end{array}$ & $\begin{array}{l}\mathrm{CL}_{\mathrm{t}+1} \\
\mathrm{UE}_{\mathrm{t}+1}\end{array}$ & $\begin{array}{l}\mathrm{CL}_{\mathrm{t}+1}{ }^{*} \\
\mathrm{MAR}_{\mathrm{t}+1}\end{array}$ \\
\hline $\mathrm{MAR}_{\mathrm{t}}$ & 1.00 & & & & & & & & & \\
\hline $\mathrm{UE}_{\mathrm{t}-1}$ & 0.07 & 1.00 & & & & & & & & \\
\hline $\mathrm{UE}_{\mathrm{t}}$ & 0.25 & 0.34 & 1.00 & & & & & & & \\
\hline $\mathrm{UE}_{\mathrm{t}+1}$ & 0.05 & 0.14 & -0.02 & 1.00 & & & & & & \\
\hline $\mathrm{MAR}_{\mathrm{t}+1}$ & -0.12 & 0.08 & -0.01 & 0.23 & 1.00 & & & & & \\
\hline $\mathrm{CL}_{\mathrm{t}+1}$ & 0.03 & -0.08 & 0.03 & 0.12 & 0.12 & 1.00 & & & & \\
\hline $\mathrm{CL}_{\mathrm{t}+1} * \mathrm{UE}_{\mathrm{t}-1}$ & 0.10 & 0.54 & 0.20 & -0.04 & -0.03 & 0.15 & 1.00 & & & \\
\hline $\mathrm{CL}_{\mathrm{t}+1} * \mathrm{UE}_{\mathrm{t}}$ & 0.08 & 0.19 & 0.58 & -0.11 & -0.04 & 0.13 & 0.36 & 1.00 & & \\
\hline $\begin{array}{l}\mathrm{CL}_{\mathrm{t}+1} * \\
\mathrm{UE}_{\mathrm{t}+1}\end{array}$ & 0.01 & -0.05 & -0.10 & 0.60 & 0.21 & -0.03 & -0.08 & -0.16 & 1.00 & \\
\hline $\begin{array}{l}\mathrm{CL}_{\mathrm{t}+1} * \\
\mathrm{MAR}_{\mathrm{t}+1}\end{array}$ & 0.15 & 0.04 & 0.04 & 0.23 & 0.46 & -0.07 & 0.03 & 0.03 & 0.41 & 1.00 \\
\hline
\end{tabular}

Significant correlations at $\mathrm{p}<0.1$ are in bold 
Table 4

FERC Model

$$
\begin{aligned}
& M A R_{t}=\alpha_{0}+\alpha_{1} \Delta E_{t-1}+\alpha_{2} \Delta E_{t}+\alpha_{3} \Delta E_{t+1}+\alpha_{4} M A R_{t+1}+\alpha_{5} C L_{t+1}+\alpha_{6} \Delta E_{t-1} * C L_{t+1} \\
& +\alpha_{7} \Delta E_{t} * C L_{t+1}+\alpha_{8} \Delta E_{t+1} * C L_{t+1}+\alpha_{9} M A R_{t+1} * C L_{t+1}+\varepsilon_{t}
\end{aligned}
$$

All Observations

Without Influential Obs.

\begin{tabular}{ccccc|ccc}
\hline Variable & & Coefficient & t-stat & Sig. & Coefficient & t-stat & Sig. \\
\hline & $\alpha_{0}$ & 0.0347 & 0.76 & & 0.0091 & 0.27 & \\
$\Delta \mathrm{E}_{\mathrm{t}-1}$ & $\alpha_{1}$ & -0.4034 & -1.35 & & -0.2049 & -0.79 & \\
$\Delta \mathrm{E}_{\mathrm{t}}$ & $\alpha_{2}$ & 2.2280 & 7.65 & $* * *$ & 2.2972 & 8.46 & $* * *$ \\
$\Delta \mathrm{E}_{\mathrm{t}+1}$ & $\alpha_{3}$ & 0.7734 & 2.09 & $* *$ & 0.8721 & 3.20 & $* * *$ \\
$\mathrm{R}_{\mathrm{t}+1}$ & $\alpha_{4}$ & -0.5093 & -6.71 & $* * *$ & -0.4243 & -7.52 & $* * *$ \\
$\mathrm{CL}_{\mathrm{t}+1}$ & $\alpha_{5}$ & 0.1056 & 1.72 & $*$ & 0.0524 & 1.17 & \\
$\mathrm{CL}_{\mathrm{t}+1}{ }^{*} \Delta \mathrm{E}_{\mathrm{t}-1}$ & $\alpha_{6}$ & 1.1438 & 2.21 & $* *$ & 0.7709 & 1.85 & $*$ \\
$\mathrm{CL}_{\mathrm{t}+1} * \Delta \mathrm{E}_{\mathrm{t}}$ & $\alpha_{7}$ & -2.0212 & -3.85 & $* * *$ & -1.9236 & -4.60 & $* * *$ \\
$\mathrm{CL}_{\mathrm{t}+1} *$ & $\alpha_{8}$ & -1.3232 & -2.03 & $* *$ & -0.9019 & -1.91 & $* *$ \\
$\Delta \mathrm{E}_{\mathrm{t}+1}$ & & 0.6661 & 6.85 & $* * *$ & 0.4981 & 7.06 & $* * *$ \\
$\mathrm{CL}_{\mathrm{t}+1} * \mathrm{R}_{\mathrm{t}+1}$ & $\alpha_{9}$ & 0.616 & & $\mathrm{n}$ & 777 & $* *$ \\
\hline $\mathrm{n}$ & & & 816 & & & \\
$\mathrm{~F}-\mathrm{Stat}$ & & & 15.94 & $* * *$ & $\mathrm{~F}-\mathrm{Stat}$ & 18.44 & $* * *$ \\
Adj R & & & 0.1417 & & Adj R & 0.1682 & \\
High VIF & & & 1.9 & & High VIF & 2.1 & \\
\hline
\end{tabular}


Table 5

FERC Model with Additional Controls

$$
\begin{aligned}
& \operatorname{MAR}_{t}=\alpha_{0}+\alpha_{1} \Delta E_{t-1}+\alpha_{2} \Delta E_{t}+\alpha_{3} \Delta E_{t+1}+\alpha_{4} M A R_{t+1}+\alpha_{5} C L_{t+1}+\alpha_{6} \Delta E_{t-1} * C L_{t+1} \\
& +\alpha_{7} \Delta E_{t} * C L_{t+1}+\alpha_{8} \Delta E_{t+1} * C L_{t+1}+\alpha_{9} M A R_{t+1} * C L_{t+1}+\alpha_{10} \text { Lev }_{t}+\alpha_{11} \text { Size }_{t}+\varepsilon_{t}
\end{aligned}
$$

\begin{tabular}{|c|c|c|c|c|c|c|c|}
\hline \multirow[b]{2}{*}{ Variable } & & \multicolumn{3}{|c|}{ All Observations } & \multicolumn{3}{|c|}{ Without Influential Obs. } \\
\hline & & Coefficient & t-stat & Sig. & Coefficient & t-stat & Sig. \\
\hline & $\alpha_{0}$ & 0.3827 & 3.03 & $* * *$ & 0.0611 & 0.75 & \\
\hline$\Delta \mathrm{E}_{\mathrm{t}-1}$ & $\alpha_{1}$ & -0.3634 & -1.05 & & -0.0296 & -0.11 & \\
\hline$\Delta \mathrm{E}_{\mathrm{t}}$ & $\alpha_{2}$ & 2.0839 & 6.05 & $* * *$ & 1.9275 & 5.76 & $* * *$ \\
\hline$\Delta \mathrm{E}_{\mathrm{t}+1}$ & $\alpha_{3}$ & 0.0997 & 0.22 & & 0.9107 & 3.05 & $* * *$ \\
\hline $\mathrm{R}_{\mathrm{t}+1}$ & $\alpha_{4}$ & -0.4842 & -5.46 & $* * *$ & -0.3919 & -6.67 & $* * *$ \\
\hline $\mathrm{CL}_{\mathrm{t}+1}$ & $\alpha_{5}$ & 0.1782 & 2.29 & $* *$ & 0.1404 & 2.83 & $* * *$ \\
\hline $\mathrm{CL}_{\mathrm{t}+1} * \Delta \mathrm{E}_{\mathrm{t}-1}$ & $\alpha_{6}$ & 0.6525 & 1.09 & & 0.2424 & 0.56 & \\
\hline $\mathrm{CL}_{\mathrm{t}+1} * \Delta \mathrm{E}_{\mathrm{t}}$ & $\alpha_{7}$ & -1.5228 & -2.49 & $* *$ & -1.4056 & -3.03 & $* * *$ \\
\hline $\mathrm{CL}_{\mathrm{t}+1} * \Delta \mathrm{E}_{\mathrm{t}+1}$ & $\alpha_{8}$ & -1.0041 & -1.33 & & -0.8106 & -1.72 & $* *$ \\
\hline $\mathrm{CL}_{\mathrm{t}+1} * \mathrm{R}_{\mathrm{t}+1}$ & $\alpha_{9}$ & 0.6814 & 6.03 & $* * *$ & 0.5118 & 7.19 & $* * *$ \\
\hline $\operatorname{Lev}_{\mathrm{t}}$ & $\alpha_{10}$ & 0.1931 & 1.19 & & -0.0775 & -0.77 & \\
\hline Size $_{t}$ & $\alpha_{11}$ & -0.0794 & -3.84 & $* * *$ & -0.0215 & -1.64 & \\
\hline $\mathrm{n}$ & & & 580 & & $\mathrm{n}$ & 557 & \\
\hline F-Stat & & & 10.26 & $* * *$ & F-Stat & 11.71 & $* * *$ \\
\hline $\operatorname{Adj} \mathrm{R}^{2}$ & & & 0.1497 & & Adj $R^{2}$ & 0.1749 & \\
\hline High VIF & & & 1.97 & & High VIF & 2.38 & \\
\hline
\end{tabular}




\section{Table 6}

FERC Severity of Comment Letter Case

\begin{tabular}{|c|c|c|c|c|}
\hline Variable & & Coefficient & t-stat & Sig. \\
\hline & $\alpha_{0}$ & 0.1212 & 1.47 & \\
\hline$\Delta \mathrm{E}_{\mathrm{t}-1}$ & $\alpha_{1}$ & -0.3708 & -1.07 & \\
\hline$\Delta \mathrm{E}_{\mathrm{t}}$ & $\alpha_{2}$ & 1.9925 & 5.72 & $* * *$ \\
\hline$\Delta \mathrm{E}_{\mathrm{t}+1}$ & $\alpha_{3}$ & 0.6809 & 1.54 & \\
\hline $\mathrm{R}_{\mathrm{t}+1}$ & $\alpha_{4}$ & -0.5285 & -5.91 & $* * *$ \\
\hline $\mathrm{CL}_{\mathrm{t}+1}$ & $\alpha_{5}$ & 0.1184 & 1.52 & \\
\hline $\mathrm{HIGH}_{\mathrm{t}+1}$ & $\alpha_{6}$ & -0.0259 & -2.08 & $* *$ \\
\hline $\mathrm{CL}_{\mathrm{t}+1} * \Delta \mathrm{E}_{\mathrm{t}-1}$ & $\alpha_{7}$ & 0.8991 & 1.44 & \\
\hline $\mathrm{CL}_{\mathrm{t}+1} * \Delta \mathrm{E}_{\mathrm{t}}$ & $\alpha_{8}$ & -1.6843 & -2.69 & $* * *$ \\
\hline $\mathrm{CL}_{\mathrm{t}+1} * \Delta \mathrm{E}_{\mathrm{t}+1}$ & $\alpha_{9}$ & -0.8331 & -1.07 & \\
\hline $\mathrm{CL}_{\mathrm{t}+1} * \mathrm{R}_{\mathrm{t}+1}$ & $\alpha_{10}$ & 0.6918 & 3.56 & $* * *$ \\
\hline $\mathrm{CL}_{\mathrm{t}+1} * \Delta \mathrm{E}_{\mathrm{t}-1} * \mathrm{HIGH}_{\mathrm{t}+1}$ & $\alpha_{11}$ & -0.0055 & -0.06 & \\
\hline $\mathrm{CL}_{\mathrm{t}+1} * \Delta \mathrm{E}_{\mathrm{t}} * \mathrm{HIGH}_{\mathrm{t}+1}$ & $\alpha_{12}$ & 0.0256 & 0.94 & \\
\hline $\mathrm{CL}_{\mathrm{t}+1} * \Delta \mathrm{E}_{\mathrm{t}+1} * \mathrm{HIGH}_{\mathrm{t}+1}$ & $\alpha_{13}$ & -0.0239 & -1.55 & \\
\hline $\mathrm{CL}_{\mathrm{t}+1} * \mathrm{R}_{\mathrm{t}+1} * \mathrm{HIGH}_{\mathrm{t}+1}$ & $\alpha_{14}$ & -0.0005 & -0.01 & \\
\hline $\mathrm{n}$ & & & 580 & \\
\hline F-Stat & & & 7.19 & $* * *$ \\
\hline Adj $R^{2}$ & & & 0.1300 & \\
\hline High VIF & & & 3.56 & \\
\hline
\end{tabular}




\section{Table 7}

\section{Category Definitions}

\begin{tabular}{|c|c|}
\hline Sub-Category- order & Definition \\
\hline SFAS & Accounting issues related to FASB statements. \\
\hline Registration & Issues particular to the Registration statement. \\
\hline GAAP & $\begin{array}{l}\text { Accounting and disclosure issues dealing with generally accepted accounting } \\
\text { principles. }\end{array}$ \\
\hline Regulation S-K & Issues related to Regulation S-K. \\
\hline MD\&A & $\begin{array}{l}\text { Taken from disclosures that are typical of the requirements for each registrant's } \\
\text { Management Discussion and Analysis }\end{array}$ \\
\hline Event Disclosures & Identifies SEC comments about particular event or $8 \mathrm{~K}$ disclosures \\
\hline Risk Factors & $\begin{array}{l}\text { Issues dealing with inadequate disclosure of risk factors in firms' Exchange Act } \\
\text { reports. }\end{array}$ \\
\hline Regulation S-X & Captures SEC Comment Letter citations related to REG S-X. \\
\hline ETIF & Issues related to the emerging issues task force. \\
\hline Other disclosures & Disclosure issues that do not fit well in other categories. \\
\hline Whole letter & Issues dealing with the entire comment letter. \\
\hline SEC Staff Accounting Bulletins & Issues addressed in the SEC Staff Accounting Bulletins \\
\hline Legal Matters & Issues related to legal matters and/or court cases in a comment letter. \\
\hline Fin Guide & Issues addressed within the FASB Interpretations. \\
\hline Internal \& Disclosure Controls & Comment letter issues related to internal control and disclosure control \\
\hline Tender Offers & Comment letter issues related to tender offers. \\
\hline Regulation M-A & Comment letter issues addressed within Regulation M-A. \\
\hline FASB Staff Bulletins & Comment letter issues addressed within FASB Staff positions. \\
\hline IFRS & Issues related to International Financial Reporting Standards (IFRS) \\
\hline FASB Technical Bulletins & Issues discussed with FASB Technical Bulletins \\
\hline IAS & Issues addressed within International Accounting Standards (IAS) \\
\hline $\mathrm{SIC}$ & $\begin{array}{l}\text { Issues addressed in the Standing Interpretations Committee (SIC), issued before } \\
2001\end{array}$ \\
\hline IFRIC & $\begin{array}{l}\text { Issues addressed in the Interpretations of the International Financial Reporting } \\
\text { Interpretations Committee (IFRIC) issued after } 2001 .\end{array}$ \\
\hline
\end{tabular}


Table 8

Comment Letters across DCF Offices for the 2005 -2009 Period

\begin{tabular}{|c|c|c|c|c|c|c|c|c|}
\hline & & \multicolumn{4}{|c|}{ Panel A } & \multicolumn{3}{|c|}{ Panel B } \\
\hline & Division of Corporate Finance (DCF) Office & Firms & Cases & $\begin{array}{c}\text { SEC } \\
\text { Comment } \\
\text { Letters }\end{array}$ & $\begin{array}{l}\text { Unique } \\
\text { Issues }\end{array}$ & $\begin{array}{c}\text { Initial } \\
\text { Response }\end{array}$ & $\begin{array}{l}\text { Avg. } \\
\text { Rounds }\end{array}$ & $\begin{array}{l}\text { Avg. Days } \\
\text { to } \\
\text { Resolution }\end{array}$ \\
\hline 1 & Health Care and Insurance & 910 & 1,356 & 4,436 & 25,034 & 21.40 & 6.60 & 68.70 \\
\hline 2 & Consumer Products & 666 & 918 & 3,271 & 27,265 & 44.86 & 6.50 & 68.21 \\
\hline 3 & Computers and Online Services & 866 & 1,303 & 4,621 & 30,693 & 49.95 & 6.83 & 72.96 \\
\hline 4 & Natural Resources and Food & 1,157 & 1,563 & 5,370 & 33,893 & 22.42 & 6.59 & 77.19 \\
\hline 5 & Structured Finance, Transportation, and Leisure & 909 & 1,211 & 3,957 & 29,338 & 21.83 & 5.78 & 60.30 \\
\hline 6 & Manufacturing and Construction & 1,050 & 1,441 & 5,543 & 43,393 & 20.26 & 6.82 & 66.75 \\
\hline 7 & Financial Services & 871 & 1,097 & 3,594 & 21,148 & 18.14 & 5.93 & 59.03 \\
\hline 8 & Real Estate and Business Services & 809 & 1,098 & 3,841 & 21,779 & 23.63 & 6.20 & 60.36 \\
\hline 9 & Beverages, Apparel, and Health Care Services & 632 & 863 & 2,771 & 19,158 & 17.55 & 5.90 & 60.58 \\
\hline 10 & Electronics and Machinery & 986 & 1,451 & 4,600 & 33,329 & 18.28 & 5.72 & 60.45 \\
\hline 11 & Telecommunications & 897 & 1,193 & 4,032 & 27,959 & 30.07 & 6.38 & 64.80 \\
\hline \multirow[t]{2}{*}{23} & Business Services, NEC & 337 & 459 & 1,671 & 10,632 & 48.28 & 6.46 & 68.59 \\
\hline & Total & 10,090 & 13,953 & 47,707 & 323,621 & & & \\
\hline
\end{tabular}


TABLE 9

Most Frequent Filings

\begin{tabular}{|l|l|}
\hline Filing & Definition \\
\hline $10 \mathrm{~K}$ & An annual report that provides a comprehensive summary of firm performance \\
\hline $10 \mathrm{Q}$ & A quarterly filing that provides a comprehensive summary of firm performance. \\
\hline $10 \mathrm{KSB}$ & $\begin{array}{l}\text { Annual report for small business (companies with less than } \$ 10 \text { million in assets whose securities are held } \\
\text { by less than 500 owners) which could be filed until March } 16,2009\end{array}$ \\
\hline $8-\mathrm{K}$ & Reports material events or changes which are of importance to investors. \\
\hline $10 \mathrm{QSB}$ & Quarterly small business filing that provides a comprehensive summary of firm performance. \\
\hline DEF 14A & $\begin{array}{l}\text { Report filed with the SEC and sent to shareholders with material information on corporate matters subject } \\
\text { to vote at the annual meeting. }\end{array}$ \\
\hline $10-\mathrm{K} / \mathrm{A}$ & Amendment to original 10-K filing \\
\hline $10-\mathrm{K} / \mathrm{SBA}$ & Amendment to original 10-K filing for small businesses \\
\hline & $\begin{array}{l}\text { Amendment to the original form S-1 which is a filing used by public companies to register securities with } \\
\text { the SEC. }\end{array}$ \\
\hline S-1/A & $\begin{array}{l}\text { SEC filing submitted by certain foreign private issuers to either register securities, provide annual report, } \\
\text { change fiscal year or operate as a shell company. }\end{array}$ \\
\hline
\end{tabular}


Table 10

Top Comment Letter Issues by Categories

\begin{tabular}{|c|c|c|c|c|c|}
\hline \multicolumn{2}{|r|}{ GAAP as Authority } & \multicolumn{2}{|r|}{ Registration Statement } & \multicolumn{2}{|r|}{ FASB as Authority } \\
\hline 1 & Debt, quasi-debt, warrants \& equity & 1 & Signatures/exhibits/agreements & 1 & SFAS 131: Segment Disclosures \\
\hline 2 & Revenue recognition issues & 2 & $\begin{array}{l}\text { Request to accelerate or expedite } \\
\text { registration }\end{array}$ & 2 & SFAS 133: Derivatives \\
\hline 3 & Fair value measurement, estimates, use & 3 & $\begin{array}{l}\text { Terms of the offering--explain, clarify, } \\
\text { or justify }\end{array}$ & 3 & SFAS 123 R: Stock Options \\
\hline 4 & $\begin{array}{l}\text { Acquisitions, mergers, and business } \\
\text { combinations }\end{array}$ & 4 & $\begin{array}{l}\text { Update registration and/or fill in } \\
\text { missing information }\end{array}$ & 4 & SFAS 95: Statement of Cash Flow \\
\hline \multirow[t]{2}{*}{5} & $\begin{array}{l}\text { Deferred, stock-based and/or executive } \\
\text { comp issues }\end{array}$ & 5 & Legality opinion issues or requirements & 5 & SFAS 142: Goodwill, other intangibles \\
\hline & Regulation S-K as Authority & \multicolumn{2}{|r|}{ MD\&A } & \multicolumn{2}{|r|}{ Risk Factor Disclosures } \\
\hline 1 & Reg S-K: Exhibits & 1 & Executive compensation disclosure & 1 & Inadequate disclosure of risk \\
\hline 2 & Reg S-K: Executive Comp & 2 & Liquidity & 2 & Legal exposures, reliance, claims etc. \\
\hline 3 & Reg S-K: MD\&A & 3 & Business overview & 3 & Reliance on suppliers, customers, gov't \\
\hline 4 & Reg S-K: Future Projections & 4 & Critical Accounting Policies and Est. & 4 & Conflicts of interest/related party \\
\hline 5 & Reg S-K: Summary Comp.Table & 5 & Results of Operations & 5 & Reliance on certain personnel \\
\hline \multicolumn{2}{|r|}{ Regulation S-X as Authority } & \multicolumn{2}{|r|}{ Events or 8-K Disclosures } & \multicolumn{2}{|r|}{ ETIF as Authority } \\
\hline 1 & $\begin{array}{l}\text { Article 5: Commercial, Industrial } \\
\text { Companies }\end{array}$ & 1 & 8-K Disclosure & 1 & EITF 00-19: Accounting for Derivatives \\
\hline 2 & Article 3: General Instruction for $\mathrm{F} / \mathrm{S}$ & 2 & Audit(or) consent re: opinions in $\mathrm{f} / \mathrm{s}$ & 2 & $\begin{array}{l}\text { EITF 00-21: Revenue Multi. } \\
\text { Deliverables }\end{array}$ \\
\hline 3 & Article 11: Pro Forma F/S & 3 & $\begin{array}{l}\text { Restatement, accounting error- } \\
\text { disclosure }\end{array}$ & 3 & EITF 98-5: Convertible Debt \\
\hline 4 & Article 4: General Application & 4 & Auditor departure disclosure & 4 & EITF 00-27: Convertible Instruments \\
\hline 5 & Rule 3-12: Age of F/S & 5 & Auditor Independence & 5 & EITF 99-19Revenue Gross or Net \\
\hline
\end{tabular}


Table 11

Top Comment Letter Issues for the 2005-2009 Period

2005

\begin{tabular}{|l|l|l|}
\hline \multicolumn{1}{|c|}{ Issue \#1 } & Issue \#2 & Issue \#3 \\
\hline $\begin{array}{l}\text { Debt, quasi-debt, warrants \& } \\
\text { equity }\end{array}$ & Revenue recognition & Disclosure Control reporting \\
\hline
\end{tabular}

2006

\begin{tabular}{|l|l|l|}
\hline \multicolumn{1}{|c|}{ Issue $\# 1$} & \multicolumn{1}{|c|}{ Issue \#2 } & \multicolumn{1}{c|}{ Issue \#3 } \\
\hline $\begin{array}{l}\text { Debt, quasi-debt, warrants \& } \\
\text { equity }\end{array}$ & Revenue recognition & $\begin{array}{l}\text { Acquisitions, mergers, and } \\
\text { business combinations }\end{array}$ \\
\hline
\end{tabular}

2007

\begin{tabular}{|l|l|l|}
\hline \multicolumn{1}{|c|}{ Issue \#1 } & \multicolumn{1}{|c|}{ Issue \#2 } & \multicolumn{1}{c|}{ Issue \#3 } \\
\hline $\begin{array}{l}\text { Deferred, stock-based and/or } \\
\text { executive comp }\end{array}$ & $\begin{array}{l}\text { Debt, quasi-debt, warrants \& } \\
\text { equity }\end{array}$ & Revenue recognition \\
\hline
\end{tabular}

2008

\begin{tabular}{|c|l|l|}
\hline \multicolumn{1}{|c|}{ Issue \#1 } & \multicolumn{1}{|c|}{ Issue \#2 } & \multicolumn{1}{c|}{ Issue \#3 } \\
\hline Signatures/exhibits/ agreements & $\begin{array}{l}\text { Executive compensation plan } \\
\text { disclosure }\end{array}$ & Disclosure Control reporting \\
\hline
\end{tabular}

2009

\begin{tabular}{|l|l|l|}
\hline \multicolumn{1}{|c|}{ Issue \#1 } & Issue \#2 & \multicolumn{1}{c|}{ Issue \#3 } \\
\hline $\begin{array}{l}\text { Executive compensation plan } \\
\text { disclosure issues }\end{array}$ & Signatures/exhibits/ agreements & Reg. S-K Item 601:Exhibits \\
\hline
\end{tabular}




\section{Table 12}

Top Comment Letter Issues by DCF Office

DCF Office 1: Healthcare

\begin{tabular}{|c|l|l|}
\hline \multicolumn{1}{|c|}{ Issue \#1 } & \multicolumn{1}{|c|}{ Issue \#2 } & \multicolumn{1}{c|}{ Issue \#3 } \\
\hline Revenue recognition & Signatures/exhibits/agreements & $\begin{array}{l}\text { Debt, quasi-debt, warrants \& } \\
\text { equity }\end{array}$ \\
\hline
\end{tabular}

DCF Office 2: Consumer Products

\begin{tabular}{|c|c|c|}
\hline Issue \#1 & Issue \#2 & Issue \#3 \\
\hline Signatures/exhibits/agreements & Debt, quasi-debt, warrants \& equity & Disclosure Control reporting \\
\hline
\end{tabular}

DCF Office 3: Computers and Online Services

\begin{tabular}{|l|l|l|}
\hline \multicolumn{1}{|c|}{ Issue \#1 } & \multicolumn{1}{|c|}{ Issue \#2 } & \multicolumn{1}{c|}{ Issue \#3 } \\
\hline Revenue recognition & Disclosure Control reporting & $\begin{array}{l}\text { Fair value measurement, } \\
\text { estimates, use }\end{array}$ \\
\hline
\end{tabular}

\section{DCF Office 4: Natural Resources and Food}

\begin{tabular}{|l|l|l|}
\hline \multicolumn{1}{|c|}{ Issue \#1 } & \multicolumn{1}{|c|}{ Issue \#2 } & Issue \#3 \\
\hline $\begin{array}{l}\text { Oil, Gas and Mining Reserve } \\
\text { reporting }\end{array}$ & Signatures/exhibits/agreements & Disclosure Control reporting \\
\hline
\end{tabular}

DCF Office 5: Structured Finance, Transportation and Leisure

\begin{tabular}{|l|l|l|}
\hline \multicolumn{1}{|c|}{ Issue \#1 } & \multicolumn{1}{|c|}{ Issue \#2 } & \multicolumn{1}{c|}{ Issue \#3 } \\
\hline $\begin{array}{l}\text { Debt, quasi-debt, warrants \& } \\
\text { equity }\end{array}$ & Revenue recognition & $\begin{array}{l}\text { PPE - Intangible assets and } \\
\text { goodwill }\end{array}$ \\
\hline
\end{tabular}

DCF Office 6: Manufacturing and Construction

\begin{tabular}{|l|l|l|}
\hline \multicolumn{1}{|c|}{ Issue \#1 } & Issue \#2 & \multicolumn{1}{c|}{ Issue \#3 } \\
\hline $\begin{array}{l}\text { Fin statement segment reporting } \\
\text { (FAS 131) }\end{array}$ & Debt, quasi-debt, warrants \& equity & Signatures/exhibits/agreements \\
\hline
\end{tabular}

\section{DCF Office 7: Financial Services}

\begin{tabular}{|l|l|l|}
\hline \multicolumn{1}{|c|}{ Issue \#1 } & \multicolumn{1}{|c|}{ Issue \#2 } & \multicolumn{1}{|c|}{ Issue \#3 } \\
\hline $\begin{array}{l}\text { Loans receivable, valuation and } \\
\text { allowances }\end{array}$ & $\begin{array}{l}\text { Fair value measurement, estimates, } \\
\text { use }\end{array}$ & $\begin{array}{l}\text { Investments (SFAS 115) and cash } \\
\text { and cash equivalents }\end{array}$ \\
\hline
\end{tabular}


DCF Office 8: Real Estate and Business Services

\begin{tabular}{|c|c|l|}
\hline Issue \#1 & Issue \#2 & \multicolumn{1}{|c|}{ Issue \#3 } \\
\hline Signatures/exhibits/agreements & Debt, quasi-debt, warrants \& equity & $\begin{array}{l}\text { Acquisitions, mergers, and } \\
\text { business combinations }\end{array}$ \\
\hline
\end{tabular}

DCF Office 9: Beverages, Apparel and Health Care Services

\begin{tabular}{|l|l|l|}
\hline \multicolumn{1}{|c|}{ Issue \#1 } & \multicolumn{1}{|c|}{ Issue \#2 Issue \#3 } \\
\hline Signatures/exhibits/agreements & Debt, quasi-debt, warrants \& equity & $\begin{array}{l}\text { Disclosure Control reporting } \\
\text { issues }\end{array}$ \\
\hline
\end{tabular}

\section{DCF Office 10:Electronics and Machinery}

\begin{tabular}{|l|l|l|}
\hline \multicolumn{1}{|c|}{ Issue \#1 } & \multicolumn{1}{|c|}{ Issue \#2 } & \multicolumn{1}{c|}{ Issue \#3 } \\
\hline Revenue recognition & Signatures/exhibits/agreements & $\begin{array}{l}\text { Debt, quasi-debt, warrants \& } \\
\text { equity }\end{array}$ \\
\hline
\end{tabular}

DCF Office 11: Telecommunications

\begin{tabular}{|l|l|l|}
\hline \multicolumn{1}{|c|}{ Issue \#1 } & \multicolumn{1}{|c|}{ Issue \#2 } & \multicolumn{1}{c|}{ Issue \#3 } \\
\hline $\begin{array}{l}\text { PPE - Intangible assets and } \\
\text { goodwill }\end{array}$ & Revenue recognition & $\begin{array}{l}\text { Debt, quasi-debt, warrants \& } \\
\text { equity }\end{array}$ \\
\hline
\end{tabular}

DCF Office 23: Business Services

\begin{tabular}{|c|c|c|}
\hline Issue \#1 & Issue \#2 & \multicolumn{1}{c|}{ Issue \#3 } \\
\hline Signatures/exhibits/agreements & Debt, quasi-debt, warrants \& equity & $\begin{array}{l}\text { Acquisitions, mergers, and } \\
\text { business combinations }\end{array}$ \\
\hline
\end{tabular}


Table 13

Issue Analysis Comparing Small and Large Filers

DCF Office 1: Healthcare

\begin{tabular}{|l|l|l|l|}
\hline Firm Size & \multicolumn{1}{|c|}{ Issue \#1 } & \multicolumn{1}{c|}{ Issue \#2 } & \multicolumn{1}{c|}{ Issue \#3 } \\
\hline Large Filers (10K/10Q) & Revenue recognition & Loss reserves disclosure & Exhibit Disclosure \\
\hline Small Filers (10KSB/10QSB) & $\begin{array}{l}\text { Disclosure Control } \\
\text { reporting }\end{array}$ & $\begin{array}{l}\text { Debt, quasi-debt, warrants, } \\
\text { equity }\end{array}$ & $\begin{array}{l}\text { Acquisition, merger, } \\
\text { combination }\end{array}$ \\
\hline
\end{tabular}

DCF Office 2: Consumer products

\begin{tabular}{|l|l|l|l|}
\hline Firm Size & \multicolumn{1}{|c|}{ Issue \#1 } & \multicolumn{1}{|c|}{ Issue \#2 } & \multicolumn{1}{c|}{ Issue \#3 } \\
\hline Large Filers (10K/10Q) & MD\&A Disclosure & Exhibit Disclosure & $\begin{array}{l}\text { Fin statement segment } \\
\text { reporting }\end{array}$ \\
\hline Small Filers (10KSB/10QSB) & $\begin{array}{l}\text { Disclosure Control } \\
\text { reporting }\end{array}$ & $\begin{array}{l}\text { Debt, quasi-debt, warrants, } \\
\text { equity }\end{array}$ & Exhibit Disclosure \\
\hline
\end{tabular}

DCF Office 3: Computers and Online Services

\begin{tabular}{|l|l|l|l|}
\hline Firm Size & \multicolumn{1}{|c|}{ Issue \#1 } & \multicolumn{1}{c|}{ Issue \#2 } & \multicolumn{1}{c|}{ Issue \#3 } \\
\hline Large Filers (10K/10Q) & Revenue recognition & Exhibit Disclosures & Disclosure Control reporting \\
\hline Small Filers (10KSB/10QSB) & $\begin{array}{l}\text { Disclosure Control } \\
\text { reporting }\end{array}$ & Revenue recognition & $\begin{array}{l}\text { Debt, quasi-debt, warrants \& } \\
\text { equity }\end{array}$ \\
\hline
\end{tabular}

DCF Office 4: Natural Resources and Food

\begin{tabular}{|l|l|l|l|}
\hline Firm Size & \multicolumn{1}{|c|}{ Issue \#1 } & \multicolumn{1}{|c|}{ Issue \#2 } & \multicolumn{1}{c|}{ Issue \#3 } \\
\hline Large Filers (10K/10Q) & $\begin{array}{l}\text { Oil, Gas and Mining } \\
\text { Reserve }\end{array}$ & Exhibit Disclosure & Executive Compensation \\
\hline Small Filers (10KSB/10QSB) & $\begin{array}{l}\text { Disclosure Control } \\
\text { reporting }\end{array}$ & Oil, Gas and Mining Reserve & $\begin{array}{l}\text { Debt, quasi-debt, warrants, } \\
\text { equity }\end{array}$ \\
\hline
\end{tabular}


DCF Office 5: Structured Finance, Transportation, and Leisure

\begin{tabular}{|c|c|c|c|}
\hline Firm Size & Issue \#1 & Issue \#2 & Issue \#3 \\
\hline Large Filers (10K/10Q) & $\begin{array}{l}\text { PPE: Intangible assets \& } \\
\text { goodwill }\end{array}$ & $\begin{array}{l}\text { Debt, quasi-debt, } \\
\text { warrants,equity }\end{array}$ & Executive Compensation \\
\hline Small Filers (10KSB/10QSB) & $\begin{array}{l}\text { Debt, quasi-debt, warrants } \\
\& \text { equity }\end{array}$ & $\begin{array}{l}\text { Liabilities, payables, and } \\
\text { accrual estimate }\end{array}$ & $\begin{array}{l}\text { Fair value measurement, } \\
\text { estimates, use }\end{array}$ \\
\hline
\end{tabular}

\section{DCF Office 6: Manufacturing and Construction}

\begin{tabular}{|l|l|l|l|}
\hline Firm Size & \multicolumn{1}{|c|}{ Issue \#1 } & \multicolumn{1}{c|}{ Issue \#2 } & \multicolumn{1}{c|}{ Issue \#3 } \\
\hline Large Filers (10K/10Q) & $\begin{array}{l}\text { Fin statement segment } \\
\text { reporting }\end{array}$ & Exhibit Disclosure & $\begin{array}{l}\text { PPE: Intangible assets and } \\
\text { goodwill }\end{array}$ \\
\hline Small Filers (10KSB/10QSB) & $\begin{array}{l}\text { Disclosure Control } \\
\text { reporting }\end{array}$ & $\begin{array}{l}\text { Debt, quasi-debt, warrants, } \\
\text { equity }\end{array}$ & Revenue recognition \\
\hline
\end{tabular}

\section{DCF Office 7: Financial Services}

\begin{tabular}{|l|l|l|l|}
\hline Firm Size & \multicolumn{1}{|c|}{ Issue \#1 } & \multicolumn{1}{c|}{ Issue \#2 } & \multicolumn{1}{c|}{ Issue \#3 } \\
\hline Large Filers (10K/10Q) & $\begin{array}{l}\text { Loans receivable, } \\
\text { valuation and allowances }\end{array}$ & $\begin{array}{l}\text { Investments \& cash \& cash } \\
\text { equivalents }\end{array}$ & $\begin{array}{l}\text { Fair value measurement, } \\
\text { estimates, use (incl. VSOE) }\end{array}$ \\
\hline Small Filers (10KSB/10QSB) & $\begin{array}{l}\text { Loans receivable, } \\
\text { valuation and allowances }\end{array}$ & $\begin{array}{l}\text { Fair value measurement, } \\
\text { estimates, use }\end{array}$ & $\begin{array}{l}\text { Investments, cash, cash } \\
\text { equivalents }\end{array}$ \\
\hline
\end{tabular}

DCF Office 8: Real Estate and Business Services

\begin{tabular}{|l|l|l|l|}
\hline Firm Size & \multicolumn{1}{|c|}{ Issue \#1 } & \multicolumn{1}{c|}{ Issue \#2 } & \multicolumn{1}{c|}{ Issue \#3 } \\
\hline Large Filers (10K/10Q) & Exhibit Disclosure & Executive Compensation & $\begin{array}{l}\text { Fair value measurement, } \\
\text { estimates, use }\end{array}$ \\
\hline Small Filers (10KSB/10QSB) & $\begin{array}{l}\text { Disclosure Control } \\
\text { reporting }\end{array}$ & $\begin{array}{l}\text { Debt, quasi-debt, warrants } \\
\text { equity }\end{array}$ & $\begin{array}{l}\text { Acquisition, merger, } \\
\text { combination }\end{array}$ \\
\hline
\end{tabular}


DCF Office 9: Beverage, Apparel and Health Care Services

\begin{tabular}{|l|l|l|l|}
\hline Firm Size & \multicolumn{1}{|c|}{ Issue \#1 } & \multicolumn{1}{c|}{ Issue \#2 } & \multicolumn{1}{c|}{ Issue \#3 } \\
\hline Large Filers (10K/10Q) & Exhibit Disclosure & Executive Compensation & MD\&A \\
\hline Small Filers (10KSB/10QSB) & $\begin{array}{l}\text { Disclosure Control } \\
\text { reporting }\end{array}$ & Exhibit Disclosure & Internal Control \\
\hline
\end{tabular}

DCF Office 10: Electronics and Machinery

\begin{tabular}{|l|l|l|l|}
\hline Firm Size & \multicolumn{1}{|c|}{ Issue \#1 } & \multicolumn{1}{c|}{ Issue \#2 } & \multicolumn{1}{c|}{ Issue \#3 } \\
\hline Large Filers (10K/10Q) & Exhibit Disclosure & Revenue recognition & Disclosure Control reporting \\
\hline Small Filers (10KSB/10QSB) & $\begin{array}{l}\text { Disclosure Control } \\
\text { reporting }\end{array}$ & $\begin{array}{l}\text { Debt, quasi-debt, warrants, } \\
\text { equity }\end{array}$ & Revenue recognition \\
\hline
\end{tabular}

DCF Office 11: Telecommunications

\begin{tabular}{|l|l|l|l|}
\hline Firm Size & \multicolumn{1}{|c|}{ Issue \#1 } & \multicolumn{1}{c|}{ Issue \#2 } & \multicolumn{1}{c|}{ Issue \#3 } \\
\hline Large Filers (10K/10Q) & $\begin{array}{l}\text { PPE: Intangible assets \& } \\
\text { goodwill }\end{array}$ & Executive Compensation & $\begin{array}{l}\text { Fin statement segment } \\
\text { reporting }\end{array}$ \\
\hline Small Filers (10KSB/10QSB) & $\begin{array}{l}\text { Debt, quasi-debt, warrants } \\
\text { \& equity }\end{array}$ & $\begin{array}{l}\text { Acquisition, merger,\& } \\
\text { combination }\end{array}$ & Disclosure Control reporting \\
\hline
\end{tabular}

DCF Office 23: Business NEC

\begin{tabular}{|l|l|l|l|}
\hline Firm Size & \multicolumn{1}{|c|}{ Issue \#1 } & \multicolumn{1}{c|}{ Issue \#2 } & \multicolumn{1}{c|}{ Issue \#3 } \\
\hline Large Filers (10K/10Q) & Exhibit Disclosure & MD\&A & Executive Compensation \\
\hline Small Filers (10KSB/10QSB) & $\begin{array}{l}\text { Debt, quasi-debt, warrants } \\
\text { \& equity }\end{array}$ & $\begin{array}{l}\text { Acquisition, merger, \& } \\
\text { combination }\end{array}$ & $\begin{array}{l}\text { Fair value measurement, } \\
\text { estimates, use }\end{array}$ \\
\hline
\end{tabular}


Table 14

Descriptive Statistics for All Comment Letter Cases

\begin{tabular}{|lccccccc|}
\hline \multicolumn{7}{|c|}{ Panel A: Firm Characteristics } \\
\hline Variable & $\mathrm{n}$ & Mean & Std. & P25 & Median & P75 & $\begin{array}{c}\text { Industry Adj. } \\
\text { Mean }\end{array}$ \\
\hline Market Value & 8186 & 3809 & 10838 & 54 & 306 & 1832 & 1.24 \\
Age & 6553 & 16.16 & 15.29 & 5.83 & 11.75 & 21.33 & 1.04 \\
\hline
\end{tabular}

\begin{tabular}{|lccccccc|}
\hline \multicolumn{7}{c|}{ Panel B: Firm Performance } \\
\hline Variable & $\mathrm{n}$ & Mean & Std. & P25 & Median & P75 & $\begin{array}{c}\text { Industry Adj. } \\
\text { Mean }\end{array}$ \\
\hline ROA & 8583 & -0.32 & 1.60 & -0.09 & 0.01 & 0.07 & 1.09 \\
Book-to-Market & 7328 & 0.04 & 0.08 & 0.00 & 0.01 & 0.04 & 0.85 \\
Revenue Percent & 8737 & 0.01 & 0.03 & 0.00 & 0.00 & 0.00 & 1.17 \\
\hline
\end{tabular}

\begin{tabular}{|lccccccc|}
\hline \multicolumn{10}{|c|}{ Panel C: Risk } \\
\hline Variable & $\mathrm{n}$ & Mean & Std. & P25 & Median & P75 & $\begin{array}{c}\text { Industry Adj. } \\
\text { Mean }\end{array}$ \\
\hline Leverage & 8903 & 0.33 & 0.64 & 0.03 & 0.18 & 0.39 & 0.98 \\
Interest Coverage & 6691 & 19.02 & 234.11 & -0.52 & 4.42 & 14.17 & 1.00 \\
\hline
\end{tabular}

\begin{tabular}{|lccccccc|}
\hline \multicolumn{7}{c|}{ Panel D: Earnings Quality } \\
\hline Variable & $\mathrm{n}$ & Mean & Std. & P25 & Median & P75 & $\begin{array}{c}\text { Industry Adj. } \\
\text { Mean }\end{array}$ \\
\hline Abs. ModJones & 7440 & 1.30 & 3.38 & 0.07 & 0.21 & 0.71 & 1.09 \\
Abs. AdjJones & 7440 & 1.30 & 3.38 & 0.07 & 0.21 & 0.71 & 1.09 \\
Abs. LagJones & 6867 & 1.10 & 3.12 & 0.05 & 0.15 & 0.49 & 1.08 \\
Abs. ForwardJones & 6203 & 0.36 & 0.99 & 0.04 & 0.10 & 0.24 & 1.01 \\
Std EPS & 7005 & 0.85 & 1.48 & 0.20 & 0.42 & 0.86 & 1.02 \\
Std. CFPS & 6196 & 0.26 & 0.84 & 0.03 & 0.06 & 0.16 & 0.97 \\
Restatement & 16064 & 0.23 & 0.60 & 0.00 & 0.00 & 0.00 & 1.04 \\
\hline
\end{tabular}

\begin{tabular}{|lccccccc|}
\hline \multicolumn{7}{c|}{ Panel E: Value } \\
\hline Variable & $\mathrm{n}$ & Mean & Std. & P25 & Median & P75 & $\begin{array}{c}\text { Industry Adj. } \\
\text { Mean }\end{array}$ \\
\hline PE & 8048 & 10.40 & 42.28 & -2.63 & 10.71 & 20.46 & 1.08 \\
Share Price Volatility & 8262 & 3.79 & 11.13 & 0.53 & 1.03 & 2.49 & 0.93 \\
\hline
\end{tabular}


Table 15

Descriptive Statistics for 10K and 10Q Comment Letter Cases

\begin{tabular}{|lccccccc|c|}
\hline \multicolumn{7}{c|}{ Panel A: Firm Characteristics } & \\
\hline Variable & $\mathrm{n}$ & Mean & Std. & P25 & Median & P75 & $\begin{array}{c}\text { Industry Adj. } \\
\text { Mean }\end{array}$ & Sig. \\
\hline Market Value & 2055 & 3266 & 7601 & 167 & 660 & 2752 & 1.21 & $* * *$ \\
Age & 1878 & 19.08 & 15.49 & 8.67 & 14.17 & 25.25 & 1.23 & $* * *$ \\
\hline
\end{tabular}

\begin{tabular}{|lccccccc|c|}
\hline \multicolumn{7}{c|}{ Panel B: Firm Performance } & \\
\hline Variable & $\mathrm{n}$ & Mean & Std. & P25 & Median & P75 & $\begin{array}{c}\text { Industry Adj. } \\
\text { Mean }\end{array}$ & Sig. \\
\hline ROA & 2095 & 0.00 & 0.41 & 0.00 & 0.04 & 0.09 & 4.68 & $* * *$ \\
Book-to-Market & 1960 & 0.03 & 0.06 & 0.00 & 0.01 & 0.02 & 0.61 & $* * *$ \\
Revenue Percent & 2081 & 0.01 & 0.03 & 0.00 & 0.00 & 0.00 & 1.07 & \\
\hline
\end{tabular}

\begin{tabular}{|lccccccc|c|}
\hline \multicolumn{7}{c|}{ Panel C: Risk } & & \\
\hline Variable & $\mathrm{n}$ & Mean & Std. & P25 & Median & P75 & $\begin{array}{c}\text { Industry Adj. } \\
\text { Mean }\end{array}$ & Sig. \\
\hline Leverage & 2102 & 0.23 & 0.26 & 0.04 & 0.18 & 0.34 & 0.73 & $* * *$ \\
Interest Coverage & 1568 & 45.56 & 198.68 & 2.82 & 7.56 & 20.41 & 1.72 & $* * *$ \\
\hline
\end{tabular}

\begin{tabular}{|lccccccc|c|}
\hline \multicolumn{7}{c|}{ Panel D: Earnings Quality } & & \\
\hline Variable & $\mathrm{n}$ & Mean & Std. & P25 & Median & P75 & $\begin{array}{c}\text { Industry Adj. } \\
\text { Mean }\end{array}$ & Sig. \\
\hline Abs. ModJones & 1767 & 1.10 & 2.86 & 0.07 & 0.18 & 0.62 & 0.65 & $* * *$ \\
Abs. AdjJones & 1767 & 1.10 & 2.86 & 0.07 & 0.19 & 0.62 & 0.65 & $* * *$ \\
Abs. LagJones & 1742 & 0.85 & 2.60 & 0.05 & 0.12 & 0.35 & 0.58 & $* * *$ \\
Abs. ForwardJones & 1742 & 0.25 & 0.78 & 0.03 & 0.08 & 0.17 & 0.58 & $* * *$ \\
Std EPS & 1935 & 0.80 & 1.26 & 0.25 & 0.45 & 0.83 & 0.92 & $* * *$ \\
Std. CFPS & 1722 & 0.12 & 0.28 & 0.02 & 0.05 & 0.10 & 0.46 & $* * *$ \\
Restatement & 4039 & 0.27 & 0.65 & 0.00 & 0.00 & 0.00 & 0.97 & \\
\hline
\end{tabular}

\begin{tabular}{|lccccccc|c|}
\hline \multicolumn{7}{c|}{ Panel E: Value } & & \\
\hline Variable & $\mathrm{n}$ & Mean & Std. & P25 & Median & P75 & $\begin{array}{c}\text { Industry Adj. } \\
\text { Mean }\end{array}$ & Sig. \\
\hline PE & 2045 & 15.36 & 42.86 & 6.31 & 15.59 & 23.50 & 1.26 & \\
Share Price Volatility & 2061 & 1.47 & 3.52 & 0.44 & 0.73 & 1.33 & 0.47 & $* * *$ \\
\hline
\end{tabular}

Indicates significantly different from 1 at $\mathrm{p}<0.01 * * *, \mathrm{p}<0.05 * *, \mathrm{p}<0.10 *$. 
Table 16

Spearman Correlation Coefficients for Top Issues across DCF Offices

\begin{tabular}{|c|c|c|c|c|c|c|c|}
\hline Comment & Size & ROA & $\begin{array}{l}\text { Book } \\
\text { Mkt. }\end{array}$ & $\mathrm{PE}$ & $\begin{array}{c}\text { Rev. } \\
\%\end{array}$ & Lev. & $\begin{array}{c}\text { Int. } \\
\text { Coverage }\end{array}$ \\
\hline \multicolumn{8}{|c|}{ DCF Office \#1: Health Care and Insurance } \\
\hline Revenue Recognition & -0.21 & -0.09 & -0.02 & -0.06 & -0.05 & 0.08 & -0.09 \\
\hline $\begin{array}{l}\text { Debt, quasi-debt, warrants \& equity ( } \\
\text { BCF) security issues }\end{array}$ & -0.04 & -0.13 & -0.09 & -0.01 & -0.02 & 0.16 & -0.09 \\
\hline \multicolumn{8}{|c|}{ DCF Office \#2: Consumer Products } \\
\hline Revenue Recognition & -0.19 & -0.05 & 0.18 & -0.01 & -0.08 & -0.21 & 0.05 \\
\hline $\begin{array}{l}\text { Debt, quasi-debt, warrants \& equity ( } \\
\text { BCF) security issues }\end{array}$ & 0.08 & 0.01 & -0.07 & -0.16 & 0.12 & 0.11 & -0.05 \\
\hline \multicolumn{8}{|c|}{ DCF Office \#3: Computers and Online Services } \\
\hline Revenue Recognition & -0.03 & 0.05 & 0.08 & -0.09 & -0.03 & -0.10 & 0.03 \\
\hline $\begin{array}{l}\text { Debt, quasi-debt, warrants \& equity ( } \\
\text { BCF) security issues }\end{array}$ & 0.10 & -0.01 & -0.08 & 0.01 & 0.06 & 0.26 & -0.13 \\
\hline \multicolumn{8}{|c|}{ DCF Office \#4: Natural Resources and Food } \\
\hline Revenue Recognition & 0.01 & 0.09 & -0.02 & 0.12 & 0.12 & -0.07 & 0.17 \\
\hline $\begin{array}{l}\text { Debt, quasi-debt, warrants \& equity ( } \\
\text { BCF) security issues }\end{array}$ & 0.00 & -0.13 & -0.02 & -0.03 & -0.05 & 0.06 & -0.10 \\
\hline \multicolumn{8}{|c|}{ DCF Office \#5: Structured Finance, Transportation, and Leisure } \\
\hline Revenue Recognition & -0.01 & 0.03 & -0.01 & 0.08 & -0.02 & 0.06 & -0.04 \\
\hline $\begin{array}{l}\text { Debt, quasi-debt, warrants \& equity ( } \\
\text { BCF) security issues }\end{array}$ & -0.01 & -0.19 & 0.03 & -0.02 & -0.08 & 0.27 & -0.24 \\
\hline \multicolumn{8}{|c|}{ DCF Office \#6: Manufacturing and Construction } \\
\hline Revenue Recognition & -0.17 & 0.06 & 0.10 & -0.06 & -0.14 & -0.08 & -0.01 \\
\hline $\begin{array}{l}\text { Debt, quasi-debt, warrants \& equity ( } \\
\text { BCF) security issues }\end{array}$ & -0.14 & -0.06 & 0.11 & -0.09 & -0.10 & 0.21 & -0.19 \\
\hline \multicolumn{8}{|c|}{ DCF Office \#7: Financial Services } \\
\hline Revenue Recognition & 0.09 & 0.19 & -0.17 & -0.03 & 0.17 & 0.13 & 0.11 \\
\hline $\begin{array}{l}\text { Debt, quasi-debt, warrants \& equity ( } \\
\text { BCF) security issues }\end{array}$ & 0.12 & 0.03 & -0.06 & -0.06 & 0.15 & 0.21 & -0.02 \\
\hline \multicolumn{8}{|c|}{ DCF Office \#8: Real Estate and Business Services } \\
\hline Revenue Recognition & -0.13 & -0.05 & 0.04 & -0.09 & -0.01 & -0.14 & -0.14 \\
\hline $\begin{array}{l}\text { Debt, quasi-debt, warrants \& equity ( } \\
\text { BCF) security issues }\end{array}$ & 0.05 & -0.17 & 0.04 & -0.07 & -0.08 & 0.22 & -0.11 \\
\hline
\end{tabular}




\begin{tabular}{|c|c|c|c|c|c|c|c|}
\hline \multicolumn{8}{|c|}{ DCF Office \#9: Beverages, Apparel, and Health Care Services } \\
\hline Revenue Recognition & -0.03 & 0.06 & -0.03 & 0.11 & -0.09 & -0.14 & 0.16 \\
\hline $\begin{array}{l}\text { Debt, quasi-debt, warrants \& equity ( } \\
\text { BCF) security issues }\end{array}$ & 0.06 & -0.08 & -0.08 & -0.09 & 0.07 & 0.15 & -0.05 \\
\hline \multicolumn{8}{|c|}{ DCF Office \#10: Electronics and Machinery } \\
\hline Revenue Recognition & -0.06 & 0.00 & 0.05 & 0.06 & -0.07 & -0.06 & 0.04 \\
\hline $\begin{array}{l}\text { Debt, quasi-debt, warrants \& equity ( } \\
\text { BCF) security issues }\end{array}$ & -0.15 & -0.22 & 0.01 & -0.17 & -0.19 & 0.23 & -0.28 \\
\hline \multicolumn{8}{|c|}{ DCF Office \#11: Telecommunications } \\
\hline Revenue Recognition & -0.20 & -0.18 & 0.10 & -0.05 & -0.12 & -0.07 & -0.10 \\
\hline $\begin{array}{l}\text { Debt, quasi-debt, warrants \& equity ( } \\
\text { BCF) security issues }\end{array}$ & -0.10 & -0.30 & 0.03 & -0.16 & -0.14 & 0.18 & -0.22 \\
\hline \multicolumn{8}{|c|}{ DCF Office \#2 and 3: Business Services, NEC } \\
\hline Revenue Recognition & -0.05 & 0.02 & 0.26 & -0.04 & 0.01 & -0.14 & -0.03 \\
\hline $\begin{array}{l}\text { Debt, quasi-debt, warrants \& equity ( } \\
\text { BCF) security issues }\end{array}$ & -0.24 & -0.25 & -0.01 & -0.23 & -0.10 & 0.34 & -0.52 \\
\hline
\end{tabular}

Significant correlations $(\mathrm{p}<.05)$ are indicated in bold. 